\title{
Resonance Raman spectroscopy of Fe-S proteins and their redox properties
}

\author{
Smilja Todorovic ${ }^{1} \mathbb{D} \cdot$ Miguel Teixeira $^{1}$
}

Received: 23 October 2017 / Accepted: 14 December 2017 / Published online: 24 January 2018

(C) The Author(s) 2018, corrected publication June/2018

\begin{abstract}
Resonance Raman spectra of Fe-S proteins are sensitive to the cluster type, structure and symmetry. Furthermore, bands that originate from bridging and terminal $\mathrm{Fe}-\mathrm{S}$ vibrations in the $2 \mathrm{Fe}-2 \mathrm{~S}, 3 \mathrm{Fe}-4 \mathrm{~S}$ and $4 \mathrm{Fe}-4 \mathrm{~S}$ clusters can be sensitively distinguished in the spectra, as well as the type of non-cysteinyl coordinating ligands, if present. For these reasons, resonance Raman spectroscopy has been playing an exceptionally active role in the studies of $\mathrm{Fe}-\mathrm{S}$ proteins of diverse structures and functions. We provide here a concise overview of the structural information that can be obtained from resonance Raman spectroscopy on $\mathrm{Fe}-\mathrm{S}$ clusters, and in parallel, refer to their thermodynamic properties (e.g., reduction potential), which together define the physiological roles of $\mathrm{Fe}-\mathrm{S}$ proteins. We demonstrate how the knowledge gained over the past several decades on simple clusters nowadays enables studies of complex structures that include Fe-S clusters coupled to other centers and transient processes that involve cluster inter-conversion, biogenesis, disassembly and catalysis.
\end{abstract}

Keywords Resonance Raman spectroscopy $\cdot$ Iron-sulfur proteins $\cdot$ Reduction potential

\section{Introduction}

Resonance Raman (RR) spectroscopy is a powerful tool for identification and characterization of the metal (active) site and elucidation of structure-function relationship in metalloproteins and metalloenzymes, including hemic, iron-sulfur, diiron and copper proteins $[1,2]$. When the wavelength of the excitation laser coincides with that of an allowed electronic transition of the protein chromophore, the intensities of certain Raman bands become selectively enhanced by several orders of magnitude. In this manner selectivity also becomes enhanced along with the sensitivity, as only the vibrational modes from the chromophore that gives origin to the electronic spectrum become augmented, while those from other parts of the molecule typically cannot be observed under these conditions. In the case

The original version of this article was revised due to a retrospective Open Access order.

Smilja Todorovic

smilja@itqb.unl.pt

1 Instituto de Tecnologia Química e Biológica António Xavier, Universidade Nova de Lisboa, Av da República, 2780-157 Oeiras, Portugal of non-hemic metalloproteins, the enhanced modes mainly contain metal-ligand and intra-ligand stretching and bending vibrations, which include amino acid residues or small inorganic ligands $[1,2]$.

Over the last couple of decades, RR spectroscopy has proved to be an indispensable tool for identification and characterization of $\mathrm{Fe}-\mathrm{S}$ clusters in proteins and in particular those that are diamagnetic and therefore EPR silent (e.g., $[2 \mathrm{Fe}-2 \mathrm{~S}]^{2+}$ and $[4 \mathrm{Fe}-4 \mathrm{~S}]^{2+}$ ). RR spectra, obtained upon excitation into $\mathrm{S} \rightarrow \mathrm{Fe}$ charge transfer electronic transitions (a ligand-to-metal charge transfer transition, LMCT) are sensitive to $\mathrm{Fe}-\mathrm{S}$ cluster type, configuration and symmetry and nature of the ligands. The large body of work on synthetic clusters and simple monocluster containing proteins, mainly those involved in electron transfer (ET) (vide infra 3.1) led to a well-established assignment of their vibrational spectra and paved the way to studies of more complex systems [3-10]. More recently, RR has been shown to be capable of providing fine details on transient processes that involve $\mathrm{Fe}-\mathrm{S}$ proteins [3-10], and has been extended to surface enhanced RR (SERR) to characterize immobilized $\mathrm{Fe}-\mathrm{S}$ enzymes interacting with physiological substrates [11, 12]. Here, we aim to present an overview of RR studies on structurally and functionally different $\mathrm{Fe}-\mathrm{S}$ proteins, highlighting the type of information that can be extracted from 
RR spectra and in parallel, discuss their thermodynamic properties (e.g., reduction potential). After "Introduction", we will first briefly describe the basics of RR spectroscopy of $\mathrm{Fe}-\mathrm{S}$ proteins, together with the most commonly used approaches for determination of their redox properties. Then we will focus on the major contributions of RR spectroscopy in the studies of diverse $\mathrm{Fe}-\mathrm{S}$ proteins, such as those that participate in ET [1, 13-21], DNA repair [11], biogenesis of $\mathrm{Fe}-\mathrm{S}$ clusters [3, 22-30] and heme cofactors [31], substrate binding and activation, S-donation and catalysis [32-35], and regulation of gene expression $[5,8,10,36-39]$. We will conclude with several examples of recent RR studies of enzymes carrying complex polychromophoric clusters [7, $40,41]$.

\section{Resonance Raman spectroscopy}

RR spectra of Fe-S cluster containing proteins, obtained with a laser of wavelength that matches the energy of $\mathrm{S} \rightarrow \mathrm{Fe}$ charge transfer transitions (Fig. 1) selectively enhances modes involving the metal-ligand stretching coordinates, which can be observed in the low-frequency (200-450 $\mathrm{cm}^{-1}$ ) region [1]. RR spectra of distinct cluster types are well understood due to a thorough pioneer work

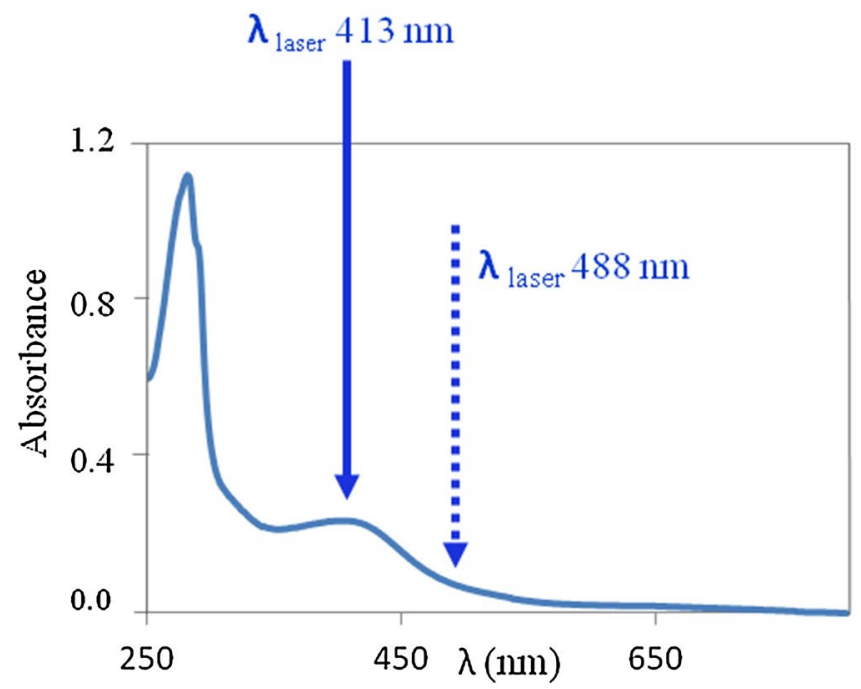

Fig. $1 \mathrm{UV}-\mathrm{Vis}$ and RR spectra of a $[4 \mathrm{Fe}-4 \mathrm{~S}]^{2+}$ cluster protein. Left panel, UV-Vis spectra with designated laser excitation wavelengths for resonance and pre-resonance enhancement of the signal. Right on isotopically labeled $\left({ }^{54} \mathrm{Fe}\right.$ and $\left.{ }^{34} \mathrm{~S}\right)$ proteins and synthetic model compounds, and normal mode analysis, which has been performed mainly by Spiro and co-workers $[1,14-16$, 18-20, 35, 42]; the assignments of Fe-S vibrational modes still largely rely on these data. There are several crucial premises that were established in those early experiments. First, different types of clusters have distinct RR fingerprints [1]. As demonstrated by systematic substitutions employing ${ }^{34} \mathrm{~S}$ in both cluster and terminal thiolate positions, bridging $(\mathrm{Fe}-\mathrm{S})^{\mathrm{b}}$ and terminal $(\mathrm{Fe}-\mathrm{S})^{\mathrm{t}}$ vibrational modes (involving inorganic sulfur and cysteinyl sulfur ligands, respectively) can be distinguished in the spectra (Fig. 1) $[1,15,18-20$, 35]. They can therefore be used as a sensitive internal probe for monitoring processes and interactions that involve these specific bonds in a cluster. However, RR spectra of distinct proteins that carry the same type of cluster may show some variations. These variations can be directly correlated with protein-specific (but typically minor) differences in $\mathrm{Fe}-\mathrm{S}$ bond strengths and $\mathrm{Fe}-\mathrm{S}-\mathrm{C}-\mathrm{C}$ dihedral angles, which govern the extent of mixing between cysteinyl $\mathrm{S}^{\mathrm{t}}-\mathrm{C}-\mathrm{C}$ bending and $(\mathrm{Fe}-\mathrm{S})^{\mathrm{t}}$ stretching modes and the complexity of the spectra $[1,16]$. Second, RR spectra are sensitive to the nature of $\mathrm{Fe}$ ligands (besides the most common $\mathrm{S}$ ligand from Cys, these may include $\mathrm{N}$ provided by His and $\mathrm{Arg}$, $\mathrm{O}$ originating
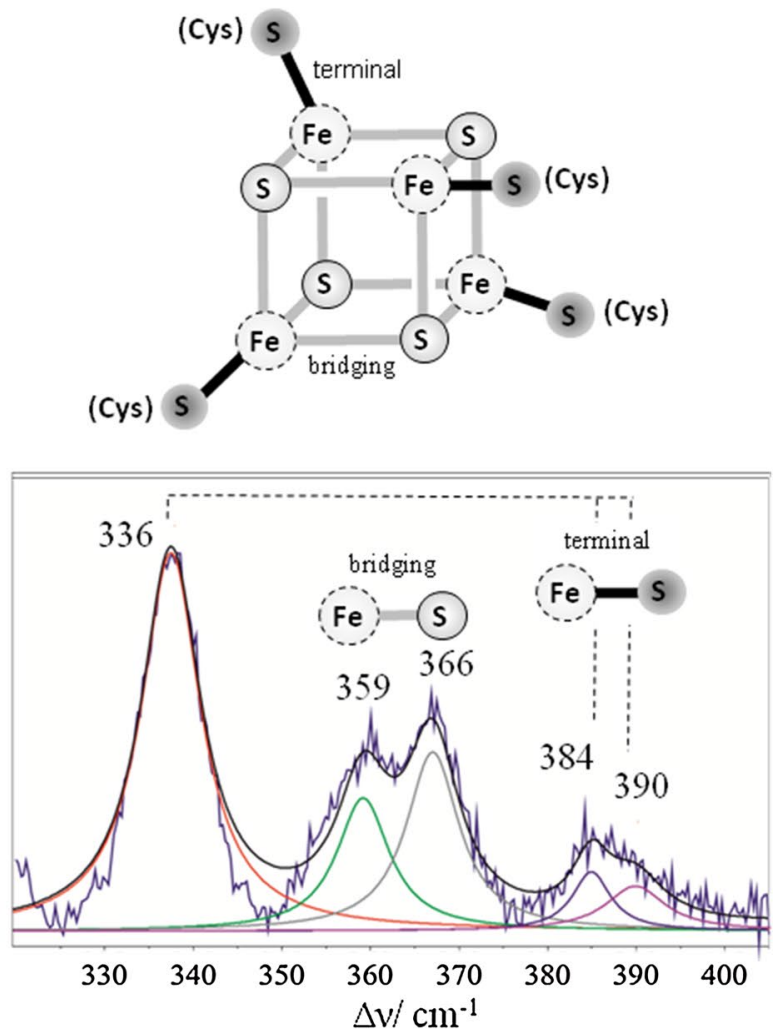

panel, experimental and deconvoluted component RR spectrum, with $\mathrm{Fe}-\mathrm{S}$ bridging and $\mathrm{Fe}-\mathrm{S}(\mathrm{Cys})$ terminal vibrational modes indicated in the spectrum and in the schematic representation of the cluster 
from Asp, Ser, Glu or Tyr and exogenous ligands), immediate molecular surrounding (polar vs. hydrophobic) and hydrogen bonding network $[1,13]$. Third, a vast majority of the published RR studies concerns analysis of oxidized clusters, since their LMCT transitions have higher intensity (and are consequently more colored). For instance, the broad electronic transition band of ferric $2 \mathrm{Fe}-2 \mathrm{~S}$ ferredoxin $(\mathrm{Fd})$, centered around $400 \mathrm{~nm}$, is twice more intense than that of the reduced $\left(\mathrm{Fe}^{3+} / \mathrm{Fe}^{2+}\right)$ form. Among obvious exceptions are High Potential Iron-sulfur Proteins (HiPIPs), which are $\mathrm{RR}$ active in the oxidized and reduced states. Besides, there are also other examples (mainly $2 \mathrm{Fe}-2 \mathrm{~S}$ cluster containing proteins) for which RR spectra were reported both for the oxidized and reduced states [42]. Fourth, by a proper choice of excitation wavelength, RR spectroscopy can simultaneously probe different types of clusters in the same protein. For instance, the $[3 \mathrm{Fe}-4 \mathrm{~S}]^{1+}$ and $[4 \mathrm{Fe}-4 \mathrm{~S}]^{2+}$ centers of $3 \mathrm{Fe}-4 \mathrm{~S} / 4 \mathrm{Fe}-4 \mathrm{~S} \mathrm{Fd}$ from Acidianus ambivalens $(A a \mathrm{Fd})$ can be simultaneously observed in RR spectra measured with $413 \mathrm{~nm}$ laser line, while the spectra measured with 458 and $514 \mathrm{~nm}$ selectively enhance the $[3 \mathrm{Fe}-4 \mathrm{~S}]^{1+}$ center [43].

The possibility to identify the cluster type, its ligands and geometry, paved a way to RR investigations of numerous and diverse $\mathrm{Fe}-\mathrm{S}$ proteins that incorporate the common $2 \mathrm{Fe}-2 \mathrm{~S}, 3 \mathrm{Fe}-4 \mathrm{~S}$ and $4 \mathrm{Fe}-4 \mathrm{~S}$ clusters and unusual heteronuclear complexes that integrate $\mathrm{Fe}-\mathrm{S}$ clusters. Furthermore, they led to remarkable studies of dynamic processes that involve cluster inter-conversion, biogenesis, disassembly and catalysis; a particularly large body of work on these transient systems comes from Johnson's group and co-workers $[3,5,8,10,13,22-28,30,32-34$, 36-39, 44].

Fig. 2 Fe-S cluster redox states and iron formal oxidation states, and reduction potential range for $\mathrm{Fe}-\mathrm{S}$ containing proteins

\section{Redox properties}

Iron-sulfur centers are intrinsically redox active, with the iron ions shuttling between the ferrous $(2+)$ and ferric $(3+)$ oxidation states. Multinuclear clusters have different combinations of ferric and ferrous ions, and are generally described by total cluster oxidation states obtained by adding the formal charges of the inorganic sulfide anions (2-) and of the ferric or ferrous ions (Fig. 2). As the cluster nuclearity increases, the number of possible oxidation states of the cluster increases as well: for example, while for the simplest $\mathrm{Fe}-\mathrm{S}$ protein, rubredoxin (Rd), only two redox states (ferric and ferrous) are accessible, for cubane clusters up to four states may be reached. However, physiologically, and in contrast with model compounds, in most $\mathrm{Fe}-\mathrm{S}$ proteins only two redox states are functional, i.e., the interactions between the cluster and the protein backbone are such that the other states are highly thermodynamically unfavoured, transforming the metal centers into simple one-electron transfer agents. Thus, $2 \mathrm{Fe}-2 \mathrm{~S}$ centers shuttle between the $2+$ (all ferric) and $1+$ (ferric/ferrous) stages; a super-reduced form (all ferrous) was electrochemically generated for the special case of the Rieske protein from the $b c_{1}$ complex $[45,46]$. Trinuclear clusters shuttle between the $1+$ (all ferric) and 0 ( 2 ferric, 1 ferrous ions) oxidation states, and again by electrochemical methods a super-reduced form was obtained in single and dicluster Fds. The transition from the $1+$ state to the 'all ferrous' 2- state involves three electrons and three protons [47-49]. For the tetranuclear clusters, two types of redox pairs exist: the HiPIP-type, for which the $[4 \mathrm{Fe}-4 \mathrm{~S}]^{3+/ 2+}$ redox states are accessible, and the Fd-type proteins, which can stabilize the $[4 \mathrm{Fe}-4 \mathrm{~S}]^{2+/ 1+}$ states. For the HiPIPs from Rodophila globiformis and Rhodospirillum salinarum, a form with

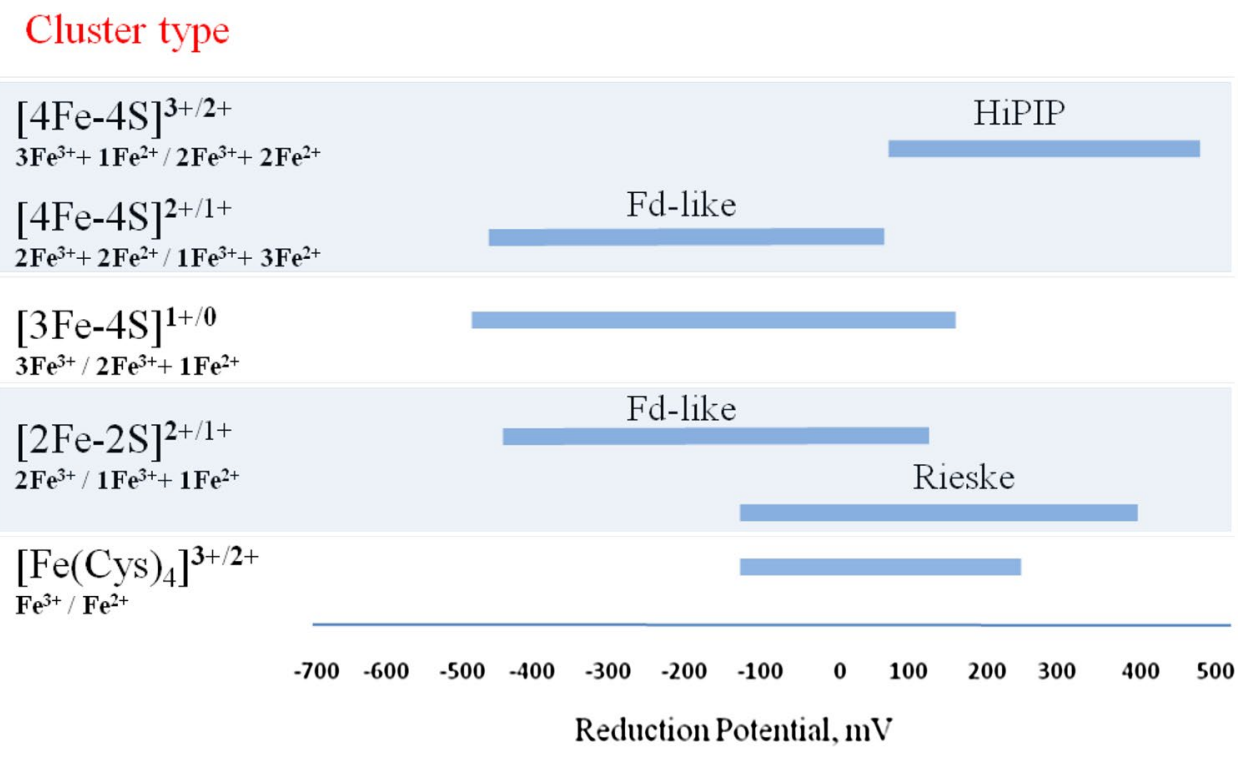

\section{Cluster type}


EPR characteristics similar to reduced Fd-type clusters, i.e., the super-reduced $[4 \mathrm{Fe}-4 \mathrm{~S}]^{1+}$ state, was obtain using the strong Ti(III)citrate reductant under basic conditions, at very low redox potentials [50]. The only example of an all-ferrous $[4 \mathrm{Fe}-4 \mathrm{~S}]^{0}$ center has been reported for the nitrogenase iron-protein [51, 52]. In all cases, the physiological significance, of the super-reduced clusters remains to be established, mainly because of the very low redox potentials at which they are formed (roughly in the -650 to $-700 \mathrm{mV}$ range).

The reduction potentials of $\mathrm{Fe}-\mathrm{S}$ proteins span almost the entire physiological range of biologically relevant redox potentials, with a parallel only in heme proteins; this variation illustrates well the fundamental role of the protein environment in fine-tuning the reduction potentials, irrespective of the cluster type (Fig. 2). Two comprehensive reviews on the redox properties of $\mathrm{Fe}-\mathrm{S}$ proteins are available $[53,54]$, therefore only a brief overview will be presented here. In Rds and Rd-like domains in more complex proteins, the reduction potentials vary roughly between -140 and $+250 \mathrm{mV}$; the lowest value was observed in the Rd-domain of flavorubredoxin from Escherichia coli [55] and the highest in the Rd-domain of rubrerythrins $[21,56]$. Differences in the reduction potentials of Rd centers have been attributed to variations in hydrogen bonds between the cysteine sulfurs and the amide groups, and to the presence of charged residues close to the center. The larger changes in reduction potentials were obtained by mutating the cysteines to serines, resulting in a $100-200 \mathrm{mV}$ decrease, which was attributed to the high electronegativity of the serinate ligand leading to a higher stabilization of the oxidized form [57, 58]. Dinuclear centers of the Rieske-type proteins (in which one of the iron ions is coordinated by two histidines, instead of the usual cysteines) have reduction potentials between -150 and $+450 \mathrm{mV}$. The negative potentials are in general associated with the so-called Rieske Fds involved in dioxygenase reactions, while the positive potentials characterize Rieske proteins of the respiratory/photosynthetic $b c_{1}$ and $b_{6} f$ complexes. In the latter, the reduction potentials are strongly $\mathrm{pH}$ dependent, and the reduction process occurs with the concomitant uptake of at least one proton, involving the histidine(s) ligand(s). The all-cysteinyl $2 \mathrm{Fe}-2 \mathrm{~S}$ clusters have negative potentials, in the range -100 to $\sim-450 \mathrm{mV}$. The difference between these and Rieske proteins has been attributed to the substitution of negatively charged cysteines by the neutral histidine imidazoles that stabilize less the oxidized cluster states. Trinuclear clusters cover also a wide range of reduction potentials, from about +150 to $\mathrm{ca}-500 \mathrm{mV}$, an interval similar to those of the Fd-like $[4 \mathrm{Fe}-4 \mathrm{~S}]^{2+/ 1+}$ centers. In contrast, the $[4 \mathrm{Fe}-4 \mathrm{~S}]^{3+/ 2+}$ transitions occur at positive potentials, ca. +50 to $+450 \mathrm{mV}$, which was rationalized in terms of structural features, the protein fold and immediate cluster surrounding, and in particular the lower number of amide-cysteinyl sulfur hydrogen bonds in HiPIPs as compared with Fd-like proteins.

\section{Methodologies}

\section{RR spectroscopy of Fe-S clusters: experimental concerns}

Raman spectroscopy is a scattering technique which, like infrared (IR) spectroscopy, probes the vibrational levels of the molecule [2]. Vibrational frequencies are sensitive to bond strength and number, geometry and coordination of atoms, and therefore provide information on molecular structures. In Raman spectroscopy the sample is irradiated (i.e., excited) with a highly monochromatic light source from a laser. Only a small fraction of the incident photons undergoes inelastic or Raman scattering, thus emerging from the sample with a different energy. The photons of shifted energy are collected together with the incident laser light, and upon filtering out of the latter, represented in the form of a Raman spectrum. Raman spectroscopy is not quantitative as the band intensity depends on the Raman cross section of the molecule. Moreover, it suffers from low sensitivity, which is due to the low quantum yield of the scattering process $\left(<10^{-9}\right)$. This disadvantage can be overcome for molecules that possess chromophoric cofactors through the resonance Raman (RR) effect [2]. In this case, matching of the energy of the incident laser light with an electronic transition of the chromophore increases the quantum yield of the scattering process by several orders of magnitude for the vibrational modes originating from the chromophore. The obtained enhancements of the Raman bands are typically around $10^{3}-10^{5}$, which ensures an increase of the sensitivity and the selectivity of RR spectra that display only the vibrational modes of the cofactor, regardless of the size of the protein matrix. It is noteworthy that the excitation energy does not have to match sharply the electronic transition; the laser wavelength can be as far as $50-100 \mathrm{~nm}$ from the absorption maximum of a chromophore, and still provide so-called "pre-resonance" enhancement (Fig. 1). Moreover, if the studied protein possesses multiple chromophores, which have distinct electronic transitions, it is in moderately complex systems often possible to selectively probe individual centers by a careful choice of excitation wavelength. For instance, one can separate contributions from $\mathrm{Fe}-\mathrm{S}$ cluster and diiron site in rubrerythrins using 568 and $496 \mathrm{~nm}$ excitations, respectively [17]; however, RR will not provide quantitative information about different types of centers due to distinct excitation profiles. Further huge enhancement of the signal can be achieved if the protein molecules are found in a close proximity of 
a nanostructured coinage metal (e.g., on Ag or Au electrodes) or a nanoparticle. In the case when the electronic transition of the molecule matches the laser wavelength (RR) and the energy of surface plasmons of the metal (surface enhanced Raman, SER), these two effects combine to give origin to surface enhanced RR spectroscopy (SERR). In comparison with RR, the sensitivity of SERR increases by another couple of orders of magnitude for the immobilized molecules [2, 59].

Good-quality RR spectra of $\mathrm{Fe}-\mathrm{S}$ cluster proteins typically require small amounts (microliter volumes) of highly concentrated sample (low millimolar concentrations), a confocal Raman spectrometer equipped with excitation laser line that fulfills the RR condition, e.g., 406, 413, 458,488 or $514 \mathrm{~nm}$ lines from krypton and argon ion laser, and relatively high laser power at a sample (often a couple of milliwatts); note that in setups in which the spectrometer is not coupled to a microscope (which ensures a high power density) these values can be $>100 \mathrm{~mW}$. Relatively high sample concentrations are required due to typically low extinction coefficients of the electronic transitions of $\mathrm{Fe}-\mathrm{S}$ cofactors; the enhancement factors roughly follow the intensities of the absorption spectrum. The sample is most commonly measured in the frozen state (e.g., $77 \mathrm{~K}$ ), which ensures narrow bandwidths. A common configuration consists of a $\mathrm{N}_{2}(1)$-cooled cryostat that carries a sample droplet, which is mounted on a microscope stage, allowing spectra collection in backscattering geometry. SERR condition is fulfilled for $\mathrm{Fe}-\mathrm{S}$ proteins attached to Ag surfaces and $413 \mathrm{~nm}$ laser; so far there are very few reports on SERR of $\mathrm{Fe}-\mathrm{S}$ proteins $[11,12]$.

After polynomial background subtraction, RR spectra are typically treated by component analysis software, which allows for accurate determination of positions, widths and intensities of the individual bands. The region of interest is in the low-frequency $\left(200-450 \mathrm{~cm}^{-1}\right)$ range, since the bands found above this interval contain overtones and combination bands; the most intense band typically originates from totally symmetric mode (Table 1 ). The band positions and relative intensities are characteristic of the particular type and symmetry of the cluster, while the band widths typically reflect homogeneity of the sample. When two distinct clusters are present in the sample, the relative intensities of their RR bands depend on respective Raman cross sections and enhancement factors.

\section{Reduction potential and its determination}

The reduction potential is a key property of the cluster in $\mathrm{Fe}-\mathrm{S}$ containing proteins, enabling to establish the nature of intra- and inter-molecular ET chains. The reduction potentials of $\mathrm{Fe}-\mathrm{S}$ proteins have been determined basically by two types of experiments: spectroscopically monitored redox titrations, in the presence of redox mediators that assure the redox equilibrium between the protein and the electrodes, and electrochemical methods, namely cyclic voltammetry (CV).

The electronic transitions of $\mathrm{Fe}-\mathrm{S}$ proteins in the $\mathrm{UV}-\mathrm{Vis}$ region are relatively weak and, furthermore, when multiple clusters are present, they result in a broad, featureless spectrum that hinders the assignment of individual clusters. The situation is much worse if the protein under study has other chromophores, namely heme centers, which have molar extinction coefficients in the visible region approximately ten times higher than $\mathrm{Fe}-\mathrm{S}$ centers. Furthermore, most redox mediators also have reasonably intense visible spectra, and therefore their concentration and type have to be carefully optimized, without compromising the redox equilibrium with the electrodes. Redox titrations are routinely monitored by UV-Vis spectroscopy in the case of the simplest $\mathrm{Fe}-\mathrm{S}$ proteins like Rds that have characteristic absorption bands in the $380-570 \mathrm{~nm}$ range in the ferric state, which are bleached upon reduction, and $2 \mathrm{Fe}-2 \mathrm{~S}$ containing proteins. The technique of choice for the determination of the redox properties of more complex $\mathrm{Fe}-\mathrm{S}$ proteins has been electron paramagnetic resonance (EPR) spectroscopy [55, 60], based on methods originally developed by Dutton [61]. Fe-S proteins have paramagnetic states, which generally display intense and characteristic EPR signals, dependent on the cluster type and oxidation state. The titrations are also performed in the presence of redox mediators [55], but since they do not interfere with the EPR signal, their concentrations may be higher and, which is particularly relevant for membrane-bound proteins (e.g., respiratory complexes) the titrations can be performed using membrane suspensions. Electrochemical methods, namely $\mathrm{CV}$, nowadays most commonly employing carbon-based working electrodes

Table 1 The common Fe-S cluster types, RR active oxidation states and the most prominent bands, $\nu\left(\mathrm{cm}^{-1}\right)$. The wavenumber interval in which the predominant RR band is found for each cluster type and the respective symmetry are designated

\begin{tabular}{|c|c|c|c|c|c|}
\hline Cluster type & {$\left[\mathrm{Fe}(\mathrm{Cys})_{4}\right]^{3+/ 2+}$} & {$[2 \mathrm{Fe}-2 \mathrm{~S}]^{2+/ 1+}$} & {$[3 \mathrm{Fe}-4 \mathrm{~S}]^{1+/ 0}$} & {$[4 \mathrm{Fe}-4 \mathrm{~S}]^{3+/ 2+/ 1+}$} & \\
\hline $\mathrm{RR}$ active redox state & $3+$ & $2+$ & $1+$ & $2+$ & $3+$ \\
\hline Predominant $\mathrm{RR}$ band $\nu\left(\mathrm{cm}^{-1}\right)$ & $314-318\left(\mathrm{~A}_{1}\right)$ & $\begin{array}{l}\text { Rieske: } 360\left(\mathrm{~B}_{2 \mathrm{t}}^{\mathrm{t}}\right) \\
\text { Fd: } 281-291\left(\mathrm{~B}_{3 \mathrm{u}}^{\mathrm{t}}\right)\end{array}$ & $346-348\left(\mathrm{~A}_{1}^{\mathrm{b}}\right)$ & HiPIP/Fd: 333-339 (A $\left.A_{1}^{b}\right)$ & HiPIP: 341-344 $\left(\mathrm{A}_{1}^{\mathrm{b}}\right)$ \\
\hline
\end{tabular}


and direct attachment of proteins, are also widely used for the determination of reduction potentials of $\mathrm{Fe}-\mathrm{S}$ proteins [62-64]. The electrochemical response is often enhanced in the presence of polycations, such as neomycin or polymyxin, when the proteins are negatively charged. Other methods rely on the adsorption of the protein onto $\mathrm{Au}$ or Ag metal working electrode surface, either bare or modified employing, e.g., SAMs (self-assembled monolayers), which facilitate protein adsorption via specific interactions and ensure biocompatibility [59]. While electrochemical methods may require small amounts of proteins, they do not allow the assignment of the detected signals to specific clusters in a protein, which is only achieved by EPR spectroscopy.

\section{RR spectroscopy of Fe-S proteins and enzymes}

\section{Electron transfer}

As mentioned above, due to a remarkable chemical versatility of both $\mathrm{Fe}$ and $\mathrm{S}, \mathrm{Fe}-\mathrm{S}$ clusters can access various redox states $[1,65]$. Consequently, one of the primary roles of $\mathrm{Fe}-\mathrm{S}$ clusters in proteins is carrying out and mediating biological ET. These functions can be undertaken by $\mathrm{FeS}_{4}$, $2 \mathrm{Fe}-2 \mathrm{~S}, 3 \mathrm{Fe}-4 \mathrm{~S}$ and $4 \mathrm{Fe}-4 \mathrm{~S}$ clusters in soluble and mobile proteins such as Rds, Fds and HiPIPs, or by clusters incorporated in domains of larger, multi-cofactor containing complexes such as respiratory chain Complexes I, II and III, hydrogenases and photosynthetic (e.g., cytochrome $b_{6} f$, photosystem I) ET complexes. While the principal role of $2 \mathrm{Fe}-2 \mathrm{~S}$ and $3 \mathrm{Fe}-4 \mathrm{~S}$ clusters is the transfer of one electron, $4 \mathrm{Fe}-4 \mathrm{~S}$ clusters carry out other diverse functions besides ET. A thorough analysis of structures of different $\mathrm{Fe}-\mathrm{S}$ proteins revealed that folds that integrate low potential $[2 \mathrm{Fe}-2 \mathrm{~S}]^{2+/ 1+}$ and $[4 \mathrm{Fe}-4 \mathrm{~S}]^{2+/ 1+}$ clusters represent a vast majority among all $\mathrm{Fe}-\mathrm{S}$ proteins, while only a very minor number of folds accommodate HiPIPs, Rieske-type and Rd proteins [66].

Rubredoxin, $\mathrm{Fe}(\mathrm{Cys})_{4}\left([1 \mathrm{Fe}]^{3+/ 2+}, 3+\right.$ state is $\mathrm{RR}$ active $)$ is a small ET protein, the simplest among $\mathrm{Fe}-\mathrm{S}$ proteins. It houses a single $\mathrm{Fe}$ ion coordinated by four cysteine sulfur atoms in distorted tetrahedral geometry ( $D_{2 d}$ symmetry). RR spectra of ferric Rd show a characteristic (not necessarily resolved) four-line pattern in the $310-380 \mathrm{~cm}^{-1}$ range (Fig. 3), which originate from $\mathrm{Fe}-\mathrm{S}$ stretching modes that involve mostly symmetric and asymmetric changes of the four $\mathrm{Fe}-\mathrm{S}$ (Cys) bond lengths [14]. Overtones and combination bands appear at higher frequencies. The most intense band, found at around $315 \mathrm{~cm}^{-1}$, Table 1, is attributed to totally symmetric breathing mode of the $\mathrm{FeS}_{4}$ tetrahedron; the bands of significantly lower intensities, centered at $\sim 360 \mathrm{~cm}^{-1}$, originate from the triply degenerate asymmetric

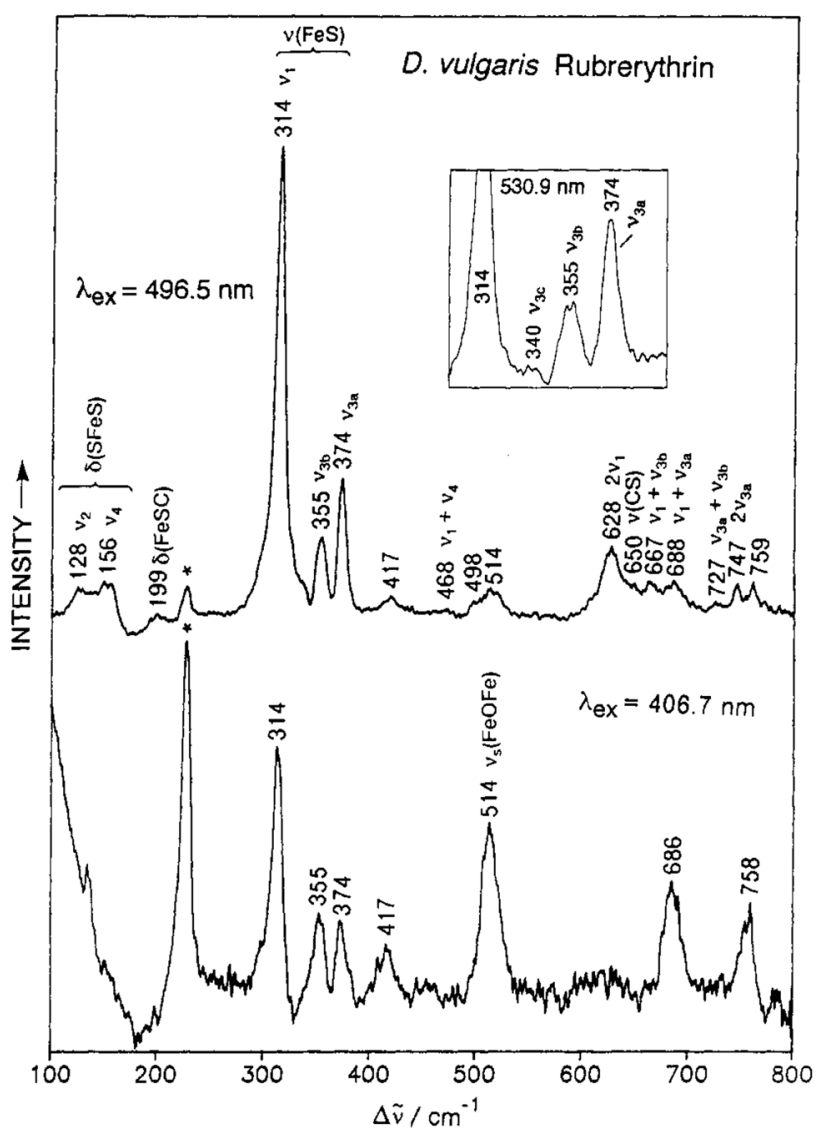

Fig. 3 Low-temperature (77 K) RR spectra of as-isolated Desulfovibrio vulgaris rubrerythrin obtained with $496 \mathrm{~nm}$ (upper trace) and $406 \mathrm{~nm}$ (lower trace) excitation wavelengths; the inset shows the $\nu_{3} \mathrm{Fe}-\mathrm{S}$ stretching region excited at $530 \mathrm{~nm}$. The bands in 300 $400 \mathrm{~cm}^{-1}$ interval represent Rd fingerprint. Reprinted with permission from Dave et al. [17]. Copyright (1994) American Chemical Society

Fe-S stretching [16]. Full understanding of the coupling between $\mathrm{Fe}-\mathrm{S}$ stretching with $\mathrm{S}-\mathrm{C}-\mathrm{C}$ bending modes in $\mathrm{Rd}$ came from normal mode analysis [67].

$\mathrm{Rd}$ center is found in more complex proteins, like rubrerythrins, desulforubrerythrins and flavorubredoxins. The spectral contributions of the two chromophores present in rubrerythrins, the $\mathrm{Rd}$ and $\mu$-oxo-bridged diiron centers, could be identified in RR spectra measured with 406 and $496 \mathrm{~nm}$ excitations. In the case of the latter, RR spectra are dominated by the modes of $\mathrm{FeS}_{4}$ tetrahedron (Fig. 3), with the symmetric stretch at $314 \mathrm{~cm}^{-1}$ and upshifted lowintensity asymmetric modes. The RR spectrum measured with $406 \mathrm{~nm}$ excitation, on the other hand, shows diminished intensities of Rd bands and a pronounced band at $514 \mathrm{~cm}^{-1}$, sensitive to ${ }^{18} \mathrm{O}$ isotopic substitution, which is characteristic of $\mathrm{Fe}-\mathrm{O}-\mathrm{Fe}$ stretch of oxo-bridged iron (Fig. 3) [17]. RR helped establish the types of cofactors in desulforubrerythrin, which was predicted to have three Fe binding structural 
domains. Broadened, overlapping bands at 316, 366 and $383 \mathrm{~cm}^{-1}$, observed with $413 \mathrm{~nm}$ excitation, were indicative of two $\mathrm{Fe}-(\mathrm{SCys})_{4}$ clusters. A simultaneously detected mode at $520 \mathrm{~cm}^{-1}$, which underwent $17 \mathrm{~cm}^{-1}$ downshift upon exchange of ${ }^{16} \mathrm{O}$ with ${ }^{18} \mathrm{O}$, was assigned to the $\mu$-oxobridged diiron center [21].

Ferredoxins carry out ET in different biological pathways, including photosynthesis and respiration, employing structurally different $\mathrm{Fe}-\mathrm{S}$ cofactors. The cluster is most commonly surrounded by hydrophobic residues, but the protein surface typically carries acidic patches that facilitate interaction with physiological redox partners [54]. $\mathrm{Fe}_{2} \mathrm{~S}_{2}(\mathrm{Cys})_{4}$ clusters (i.e., $[2 \mathrm{Fe}-2 \mathrm{~S}]^{2+/ 1+} ; 2+$ state is RR active, and less frequently $1+$ state) are found in plant-type Fds (e.g., chloroplast Fd I) and mammalian and bacterial proteins, such as adrenodoxin and putidaredoxin. The iron is coordinated by two inorganic sulfur atoms and four cysteine thiolates in distorted tetrahedral geometry (idealized $\mathrm{D}_{\mathrm{h}}$ or $\mathrm{C}_{2 \mathrm{~h}}$ symmetry) $[1,18,19]$. It is noteworthy that the assignments of iron ligand vibrational modes depend on the selected model, which may influence the interpretation of RR spectra; in particular, normal mode calculations based on models with lower symmetry can lead to overestimated $\mathrm{Fe}-\mathrm{S}(\mathrm{t})-\mathrm{C}-\mathrm{C}$ dihedral angles and $\mathrm{Fe}-\mathrm{S}$ bond strengths $[68,69]$. RR spectra of Fds are more complex and also more informative than those of Rds, since the vibrational modes that originate from mainly bridging and mainly terminal stretching modes can be distinguished in the spectra [19]. The bridging modes typically have higher energy $\left(315-425 \mathrm{~cm}^{-1}\right)$ than the terminal ones $\left(290-360 \mathrm{~cm}^{-1}\right)$. In RR spectra of ferric Fds the predominant mode $\left(B_{3 \mathrm{u}}^{\mathrm{t}}\right)$ is found around $290 \mathrm{~cm}^{-1}$ (Fig. 4), which is characteristic for all cysteinyl-coordinated clusters that are observed within the $281-291 \mathrm{~cm}^{-1}$ interval (Table 1). The presence and intensity of this mode, which should be Raman inactive due to idealized $\mathrm{D}_{2 \mathrm{~h}}$ symmetry of the center, could be rationalized in terms of hydrogen bonding in the immediate cluster environment that affects its symmetry. The other intense features of RR spectra of $2 \mathrm{Fe}-2 \mathrm{~S}$ clusters are two close modes around $320-340 \mathrm{~cm}^{-1}\left(\mathrm{~B}_{1 \mathrm{~g}}^{\mathrm{b}}\right.$ and $A_{\mathrm{g}}^{\mathrm{t}}$ ) and/or at $390-400 \mathrm{~cm}^{-1}\left(\mathrm{~A}_{\mathrm{g}}^{\mathrm{b}}\right)[19,42]$. RR bands are approx. $10 \mathrm{~cm}^{-1}$ upshifted in the clusters with an oxygenic ligand substituting one of the cysteines, which is associated with mass difference between $\mathrm{S}$ and $\mathrm{O}$ atoms. Reported $\mathrm{RR}$ spectra of ferrous $2 \mathrm{Fe}-2 \mathrm{~S}$ Fds reveal $15-40 \mathrm{~cm}^{-1}$ band shifts to lower frequencies and similar relative intensities as in the spectra of ferric proteins [42].

Fds of bacterial-type house a cubane-like $\mathrm{Fe}_{4} \mathrm{~S}_{4}(\mathrm{Cys})_{4}$ cluster $\left([4 \mathrm{Fe}-4 \mathrm{~S}]^{2+/ 1+} ; 2+\right.$ state is RR active in $\mathrm{Fds}$ and also in HiPIPs, vide infra). Evolutionary, they represent the first ubiquitous ET centers in the majority of anaerobic bacteria [54]. Typically, the most intense RR band of $4 \mathrm{Fe}-4 \mathrm{~S}$ Fds is breathing bridging $(\mathrm{Fe}-\mathrm{S})^{\mathrm{b}}$ mode of the cube at $\sim 336 \mathrm{~cm}^{-1}$ $\left(\mathrm{A}_{1}\right)$, which in the case of all cysteinyl-coordinated clusters

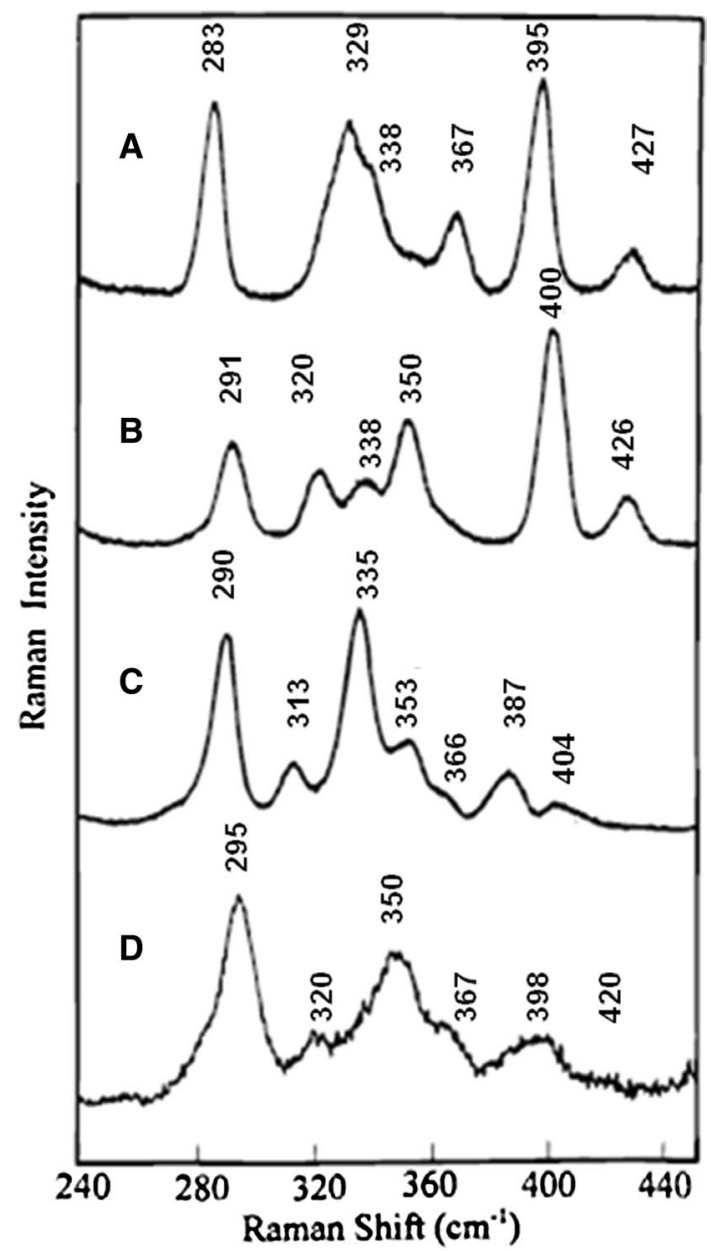

Fig. 4 Comparison of the RR spectra of oxidized human ferrochelatase (d) with three classes of $[2 \mathrm{Fe}-2 \mathrm{~S}]^{2+} \mathrm{Fds}$ : S. oleracea $\mathrm{Fd}(\mathbf{a})$, P. putida $\mathrm{Fd}$ (b), and C. pasteurianum $\mathrm{Fd}(\mathbf{c})$, recorded at $17-25 \mathrm{~K}$. Reprinted with permission from Crouse et al. [31]. Copyright (1996) American Chemical Society

falls into the $333-339 \mathrm{~cm}^{-1}$ range (Table 1$)$. The terminal modes are found around $360 \mathrm{~cm}^{-1}$ (and $390 \mathrm{~cm}^{-1}$ ). A replacement of conserved Cys by an Asp residue in $\mathrm{Fd}$ from Pyrococcus furiosus accounts for a subtle $4 \mathrm{~cm}^{-1}$ upshift of the $\mathrm{A}_{1}^{\mathrm{b}}$ breathing mode, while a replacement by a Ser residue results in a band upshift characteristic for $[4 \mathrm{Fe}-4 \mathrm{~S}]^{2+}$ clusters with oxygenic ligands $\left(340-343 \mathrm{~cm}^{-1}\right.$ range of $\mathrm{A}_{1}$ ) [13].

As a result of evolutionary gene modifications, Fds may possess $[3 \mathrm{Fe}-4 \mathrm{~S}]$ clusters in domains that have lost conserved Cys residues or multiple iron-sulfur centers (e.g., $[4 \mathrm{Fe}-4 \mathrm{~S}] /[3 \mathrm{Fe}-4 \mathrm{~S}]$ or $[4 \mathrm{Fe}-4 \mathrm{~S}] /[4 \mathrm{Fe}-4 \mathrm{~S}])$ [54]. Characteristic RR signature of oxidized $\mathrm{Fe}_{3} \mathrm{~S}_{4}(\mathrm{Cys})_{3}$ cluster $\left([3 \mathrm{Fe}-4 \mathrm{~S}]^{1+/ 0} ; 1+\right.$ state is $\mathrm{RR}$ active), present in e.g. $\mathrm{Fd}$ II from Desulfovibrio gigas, consists of bridging modes that include an intense band at $347 \mathrm{~cm}^{-1}$ and weaker ones at 266 and $285 \mathrm{~cm}^{-1}$, and terminal modes at 368 and $390 \mathrm{~cm}^{-1}$ [20]. The most intense band is the symmetric 
$\mathrm{A}_{1}^{\mathrm{b}}$ at $346-348 \mathrm{~cm}^{-1}$ (Table 1). Distinct RR fingerprints of $[4 \mathrm{Fe}-4 \mathrm{~S}]^{2+}$ and $[3 \mathrm{Fe}-4 \mathrm{~S}]^{1+}$ clusters allowed for direct observation of $3 \mathrm{Fe}-4 \mathrm{~S}$ intermediate formation upon oxidative degradation of $4 \mathrm{Fe}-4 \mathrm{~S}$ cluster in $\mathrm{Zn}$-containing Fd from $\mathrm{Sul}$ folobus sp. [70] and independent monitoring of the clusters in Fds that contain both cluster types, such as Fd from the thermoacidophile A. ambivalens $(\mathrm{A} a \mathrm{Fd})$ [43]. In the latter, differential enhancements of the bands from the two clusters was achieved employing several laser lines (e.g., 413, 458 and $514 \mathrm{~nm}$ ) (Fig. 5). The most prominent RR band is at $346 \mathrm{~cm}^{-1}$ for all three excitation wavelengths, which can be attributed to $(3 \mathrm{Fe}-4 \mathrm{~S})^{\mathrm{b}}$ mode [44]. The [4Fe-S] cluster was observable only with $413 \mathrm{~nm}$ excitation, as judged by the presence of characteristic $336 \mathrm{~cm}^{-1}$ band of the $(4 \mathrm{Fe}-4 \mathrm{~S})^{\mathrm{b}}$ mode that appears as a shoulder in the spectra (Fig. 5). Similarly, in other $[4 \mathrm{Fe}-4 \mathrm{~S}] /[3 \mathrm{Fe}-4 \mathrm{~S}]$ cluster containing Fds (e.g., Fds from Azotobacter vinelandii, Thermus thermophilus and Sulfolobus sp.), the most intense is the $(3 \mathrm{Fe}-4 \mathrm{~S})^{\mathrm{b}}$ band, regardless of the excitation wavelength [20]. The spectral contributions of the two centers in $A a \mathrm{Fd}$ were accurately determined by spectral deconvolution, which in addition to more intense bridging modes revealed the presence of terminal modes: $(3 \mathrm{Fe}-4 \mathrm{~S})^{\mathrm{t}}$ at $366 \mathrm{~cm}^{-1}$ and $(4 \mathrm{Fe}-4 \mathrm{~S})^{\mathrm{t}}$ at $358 \mathrm{~cm}^{-1}$ (Fig. 5). The possibility of simultaneous observation of the two clusters by RR spectroscopy allowed for monitoring of their individual thermally induced disassembly at the level of respective bridging and terminal bonds, in a work in which Fd was used as a model for metalloprotein (un)folding

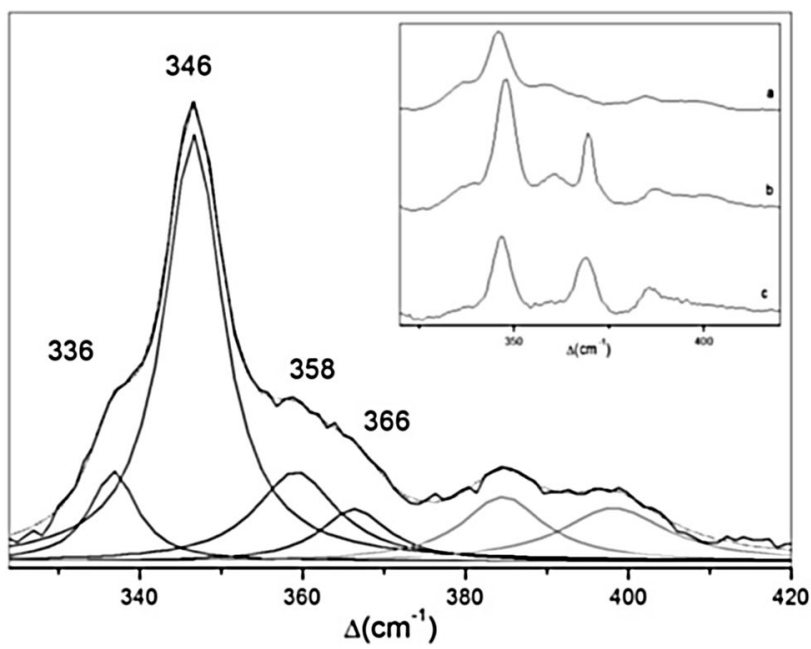

Fig. 5 Experimental and band-fitted RR spectra of oxidized 3Fe4S/4Fe-4S Fd from Acidianus ambivalens. Experimental RR spectrum (solid line) was obtained with $413 \mathrm{~nm}$ excitation and laser power of $9 \mathrm{~mW}$ at $77 \mathrm{~K}$. Overall fitted spectrum: dotted line. Component spectra: $(4 \mathrm{Fe}-4 \mathrm{~S})^{\mathrm{b}}$ at $336 \mathrm{~cm}^{-1},(3 \mathrm{Fe}-4 \mathrm{~S})^{\mathrm{b}}$ at $346 \mathrm{~cm}^{-1}$, (4Fe$4 \mathrm{~S})^{\mathrm{t}}$ at $358 \mathrm{~cm}^{-1}$ and $(3 \mathrm{Fe}-4 \mathrm{~S})^{\mathrm{t}}$ at $366 \mathrm{~cm}^{-1}$; non-assigned bands (grey); inset: comparison of RR spectra measured with 413 (a), 514 (b) and $458 \mathrm{~nm}$ (c) excitation. Adapted with permission from Todorovic et al. [43]. Copyright (2006) American Chemical Society study. It was demonstrated that the two clusters disassemble simultaneously, triggering subsequent major structural changes of secondary structural elements of the Fd [43].

Rieske centers are $\mathrm{Fe}_{2} \mathrm{~S}_{2}(\mathrm{Cys})_{2}(\mathrm{His})_{2}$ clusters (i.e., $[2 \mathrm{Fe}-2 \mathrm{~S}]^{2+/ 1+} ; 2+$ state is $\mathrm{RR}$ active) that possess a unique ligation motif involving two terminal histidine residues, in addition to two cysteinyl and two bridging sulfur atoms. They are found in $b c_{1}$ complex in mitochondria and bacteria and $b_{6} f$ complex of photosynthetic chain in chloroplasts, where they act as primary electron acceptors, and in some soluble bacterial dioxygenases [54]. Due to lower $\left(\mathrm{C}_{2 \mathrm{v}}\right)$ symmetry of the cluster, RR spectra of these proteins have a higher number of bands in the $200-450 \mathrm{~cm}^{-1}$ region than $2 \mathrm{Fe}-2 \mathrm{~S}$ Fds. The most intense is the $(\mathrm{Fe}-\mathrm{S})^{\mathrm{t}}$ stretching mode $\left(B_{2 t}\right)$, which is found around $360 \mathrm{~cm}^{-1}$ (Table 1). Other unique features of RR spectra of Rieske centers include $\mathrm{pH}$ (i.e., imidazole protonation state) sensitive $\mathrm{Fe}$-imidazole stretching $(\mathrm{Fe}-\mathrm{N}(\mathrm{His}))$, around $270 \mathrm{~cm}^{-1}$ and $\mathrm{Fe}-\mathrm{N}$ bending modes at lower frequencies. RR spectra of Rieske-type proteins can therefore provide fine details about $\mathrm{H}$ bonding network around the cluster, which plays an important role in minimizing the reorganization energy and facilitating ET in these proteins [71]. Different RR spectra and their distinct interpretation were reported for Rieske protein of the toluene-4-monooxygenase complex (T4MOC) from Pseudomonas mendocina KR1, in which the most intense $\mathrm{RR}$ band was observed at $408 \mathrm{~cm}^{-1}$ and assigned to $\mathrm{B}_{2 \mathrm{u}}^{\mathrm{b}}$ [70]. Extensive kinematic couplings of iron ligand vibrations, both of $\mathrm{Fe}-\mathrm{S}^{\mathrm{t}}$ stretching with $\delta(\mathrm{Cys})$ bending and of $\mathrm{Fe}-\mathrm{S}(\mathrm{Cys})$ stretching with $\mathrm{Fe}-\mathrm{His}$ vibrations, were observed by measuring $\mathrm{N}$ isotope effect of uniformly labeled protein. They were interpreted in terms of rigidity of terminal $\mathrm{Fe}$ ligands, imposed by hydrogen bonding and backbone constraints to ensure minimized reorganization energy for ET in T4MOC [70].

HiPIPs house a $[4 \mathrm{Fe}-4 \mathrm{~S}]^{3+/ 2+}$ cluster; both $2+$ and $3+$ states are RR active. They are found mainly in photosynthetic anaerobic bacteria, where they act as an electron carrier between the $b c_{1}$ complex and the photosynthetic reaction center, but also in aerobic bacteria, where they function as electron donors to terminal oxygen reductases. They are, therefore, to some extent comparable to the better known monohemic cytochrome $c$. RR spectra of reduced HiPIPs are quite similar to those of oxidized, isoelectronic Fds, with the most intense $A_{1}^{b}$ band at $\sim 336 \mathrm{~cm}^{-1}$. The overall complexity of the spectra may be increased by specific protein-induced distortions of the cube $[1,15]$. RR spectra of oxidized HiPIPs are also dominated by the totally symmetric bridging vibration of the $\mathrm{Fe}_{4} \mathrm{~S}_{4}$ core, which is found at $\sim 341-344 \mathrm{~cm}^{-1}$ (Table 1) [72]. Other pronounced bands (all terminal) appear at 373, 382-390, 393-403, 410 and $417-415 \mathrm{~cm}^{-1}$. The observed upshift of the $\mathrm{A}_{1}^{\mathrm{b}}$ mode (relative to the value for the reduced protein) is rationalized in 
terms of the overall shortening of $\mathrm{Fe}-\mathrm{S}^{\mathrm{b}}$ bonds. Otherwise, RR spectra of the oxidized HiPIPs from different organisms appear to be remarkably similar and also comparable to those of the respective reduced forms [72].

\section{DNA repair}

There is a growing evidence for the presence of $4 \mathrm{Fe}-4 \mathrm{~S}$ clusters in enzymes that take part in nucleic acid processing machinery [73]. These include DNA repair enzymes, such as damage-specific DNA glycosylases: endonuclease III (EndoIII), MutY and their homologue enzymes found in many organisms including humans, as well as primases, helicases, transcription factors, polymerases and RNA methyltransferases [74]. In the majority of these enzymes the role of the cluster remains to be elucidated [75].

The function and redox properties of $4 \mathrm{Fe}-4 \mathrm{~S}$ cluster in EndoIIIs have been particularly controversial, as the early studies indicated that the cluster could not be chemically oxidized or reduced in solution, suggesting that it had a structural role [76]. RR spectra of EndoIII from E. coli revealed that the cluster is $[4 \mathrm{Fe}-4 \mathrm{~S}]^{2+}$, with the most prominent bands at 337,361 and $388 \mathrm{~cm}^{-1}$. Subsequent electrochemical experiments indicated that the enzyme becomes redox active upon immobilization on electrodes coated with DNA-terminated SAMs, which led to a speculation that in the presence of DNA the cluster shuttles between $2+$ and $3+$ states, as in HiPIPs [77]. More recent evidence provided by RR and SERR spectroscopy coupled to electrochemistry, demonstrated that the $[4 \mathrm{Fe}-4 \mathrm{~S}]^{2+}$ cluster in EndoIII from Deinococcus radiodurans actually shuttles between $1+$ and $2+$ states, as in Fds, and that its redox activation is not necessarily DNA dependent $[11,12]$. Deconvolution of the spectra allowed identification of the bands at 337, 384 and $390 \mathrm{~cm}^{-1}\left((\mathrm{Fe}-\mathrm{S})^{\mathrm{b}}\right)$ and at 359 and $366 \mathrm{~cm}^{-1}\left((\mathrm{Fe}-\mathrm{S})^{\mathrm{t}}\right)$ in the RR spectra and at 337,363 and $384 \mathrm{~cm}^{-1}$ in SERR spectra (note that in the latter two modes are not resolved in SERR spectra) (Fig. 6). A comparison of the spectra demonstrates that EndoIII retains its solution structural integrity (characterized by RR) upon immobilization via strong electrostatic interactions with either DNA or $\mathrm{COO}^{-}$modified $\mathrm{Ag}$ electrodes (characterized by SERR). Furthermore, reduction of the $4 \mathrm{Fe}-4 \mathrm{~S}$ cluster of immobilized EndoIII resulted in absence of spectroscopic signal, which could be an indication of formation of reduced SERR-silent state but also of protein degradation/desorption. The SERR signal was fully recovered upon re-oxidation, demonstrating that the immobilized EndoIII was in the +1 state upon reduction. An attempt to oxidize the protein and promote the +3 state, resulted in its irreversible degradation and loss of both electrochemical (CV) and spectroscopic signals. These findings that clearly demonstrate that the cluster shuttles between +1 and +2 states were further supported by structural properties

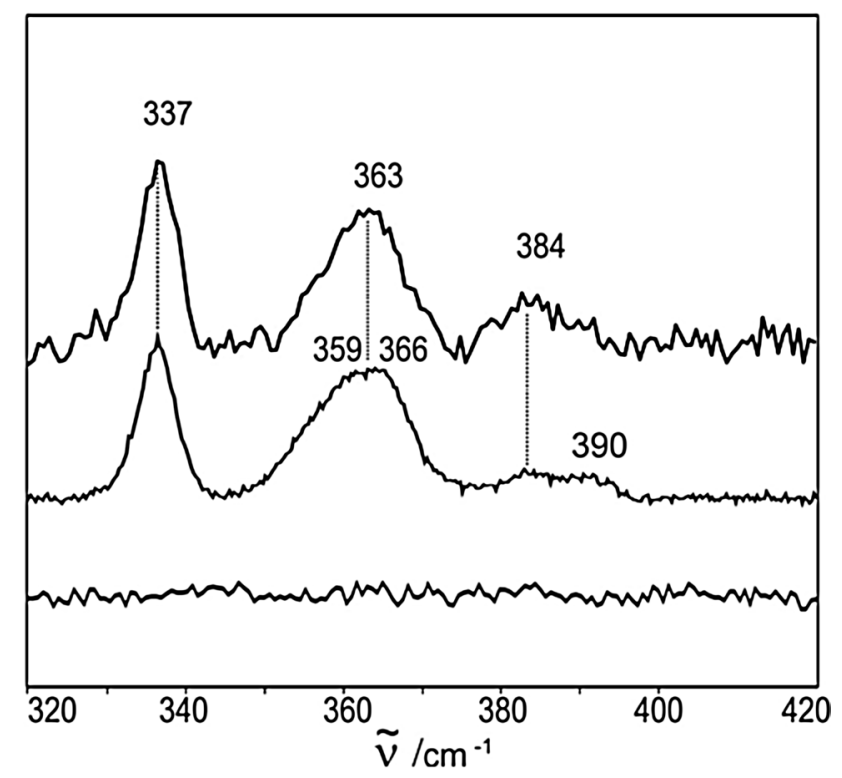

Fig. 6 SERR and RR spectra of EndoIII. SERR spectrum of EndoIII from Deinococcus radiodurans immobilized on Ag electrode modified with mercaptoundecanoic acid-terminated SAM (top trace), upon reduction with sodium dithionite (bottom trace); RR spectrum of EndoIII in frozen solution (middle trace). Spectra were measured with $413 \mathrm{~nm}$ excitation at $77 \mathrm{~K}$ using 1.5 and $8 \mathrm{~mW}$ in the SERR and RR experiments, respectively. Reproduced from Ref. [11] with permission from The Royal Society of Chemistry

of EndoIII. Namely, according to the systematic analysis of the known secondary structural elements and folds of proteins that carry $[4 \mathrm{Fe}-4 \mathrm{~S}]$ clusters (thoroughly examined and discussed in [66]), EndoIIIs belong to the group of Fdlike low redox potential $4 \mathrm{Fe}-4 \mathrm{~S}$ proteins. Taken together, this new spectroscopically based evidence demands for a revision of the mechanistic model of EndoIII glycosylases derived from electrochemical data.

\section{Fe-S cluster biosynthesis}

$\mathrm{Fe}-\mathrm{S}$ cluster biosynthesis has been an active field of research in the last two decades, and RR spectroscopy, in combination with other spectroscopic techniques (mainly UV-Vis, EPR and Mössbauer), helped disentangling several steps of this complex process, which is remarkably conserved in prokaryotic and eukaryotic organisms $[3,65]$. Relying on previously established fingerprints of different cluster types and the assignment of their vibrational modes, RR has more recently provided molecular details that are crucial for identification and characterization of the key players in the three types of bacterial $\mathrm{Fe}-\mathrm{S}$ cluster assembly machinery (NIF, ISC and SUF) [65]. They all show the common cysteine desulfurase-mediated assembly of transient clusters on scaffold proteins and subsequent transfer of pre-formed, solvent exposed clusters to cluster acceptor apo proteins of diverse 
structures and functions $[3,65]$. It is nowadays well established that in all three cases a cysteine desulfurase (IscS, SufS and NifS) provides sulfur for the biosynthesis. However, molecular details on (1) the nature of possible donors of $\mathrm{Fe}$; (2) the dynamics and inter-conversion of transiently formed clusters on scaffold proteins (e.g., IscU, SufU/SufB and NifU; note that SufU is present in Bacillus and Ralstonia species and SufB in gram-negative bacteria) and their transfer to target proteins; (3) the role of various accessory proteins, including ubiquitous A-type proteins (NifA, NufA, Isc A and SufA) in $\mathrm{Fe}-\mathrm{S}$ cluster biogenesis and maturation, together with (4) the regulation of this process, are still not well established [3, 22-30, 65, 78]. RR studies, particularly those performed by Johnson and co-workers, have contributed to the current understanding of the clusters biogenesis at different levels. First, RR has been employed in investigations of isolated components of the machinery, such as NifU and its truncated/analogous versions IscU and Nfu [23]. The former possesses a permanent redox $[2 \mathrm{Fe}-2 \mathrm{~S}]$ cluster and a site that serves as a scaffold for NifS-directed assembly of a transient cluster, while IscU can only accommodate the transient cluster. Similarly, the nature and properties of the clusters assembled on chloroplast-specific Nfu2type protein and its putative physiological cluster acceptors were characterized by RR spectroscopy [6]. The Nfu proteins represent a class of cluster carriers in numerous organisms and possess modular structure which includes a domain analogous to C-terminal domain of NifU. Like bacterial NfuA and human mitochondrial Nfu, Nfu2 from Arabidopsis thaliana was shown to be capable of assembling both, [2Fe-2S] and [4Fe-4S] clusters, which it transfers efficiently to glutaredoxin S16 and adenosine 5'-phosphosulfate reductase, respectively. The latter of the two is thought to be physiologically relevant [6]. The recombinant Nfu2 purified under anaerobic conditions contained $[2 \mathrm{Fe}-2 \mathrm{~S}]^{2+}$, while a cysteine-desulfurase-mediated anaerobic reconstitution of apo Nfu2 resulted in a form that carried $[2 \mathrm{Fe}-2 \mathrm{~S}]^{2+}$ and $[4 \mathrm{Fe}-4 \mathrm{~S}]^{2+}$ clusters. Both clusters revealed anomalously high frequencies for all-cysteinyl coordination (i.e., $\mathrm{B}_{3 \mathrm{u}}^{\mathrm{t}}$ at $295 \mathrm{~cm}^{-1}$ and $\mathrm{A}_{\mathrm{g}}^{\mathrm{t}}$ at $343 \mathrm{~cm}^{-1}$ in $[2 \mathrm{Fe}-2 \mathrm{~S}]$ and $\mathrm{A}_{1}^{\mathrm{b}}$ at $344 \mathrm{~cm}^{-1}$ in $\left.[4 \mathrm{Fe}-4 \mathrm{~S}]\right)$, which was attributed to cluster distortions associated with the subunit bridging environment [6]. Second, RR has been used as tool for monitoring of the dynamics of cluster formation and transfer [22, 65]. A typical basic assay for following of the in vitro cluster biosynthesis consists of a mixture of L-cysteine as a donor of $\mathrm{S}$, IscS that catalyzes this process, source of iron (e.g., ferric iron salt or other Fe donor) and IscU or an alternative scaffold, in a controlled reducing environment. The initial insights into formation of transient clusters were obtained from experiments in which the time course of the cluster assembly in IscU was monitored by RR spectroscopy and other methods, which revealed the nature, properties and stability of the formed cluster(s). It was demonstrated that the initial IscU product contained one $[2 \mathrm{Fe}-2 \mathrm{~S}]^{2+}$ cluster per dimer, then two of them, which were subsequently fully converted into one $4 \mathrm{Fe}-4 \mathrm{~S}$ cluster per IscU dimer [22, 23, 65]. The $4 \mathrm{Fe}-4 \mathrm{~S}$ formation in $\mathrm{IscU}$, at first described as sluggish, becomes accelerated in the presence of an efficient electron donor, through a reductive coupling of two $2 \mathrm{Fe}-2 \mathrm{~S}$ clusters assembled on IscU [26]. RR spectroscopy provided direct evidence for a gradual transformation of $2 \mathrm{Fe}-2 \mathrm{~S}$ into $4 \mathrm{Fe}-4 \mathrm{~S}$, and also for the degradation of $4 \mathrm{Fe}-4 \mathrm{~S}$ to $2 \mathrm{Fe}-2 \mathrm{~S}$ clusters upon exposure to oxygen (Fig. 7). Importantly, the frequencies of $\mathrm{RR}$ bands of $2 \mathrm{Fe}-2 \mathrm{~S}$ clusters formed in the presence of

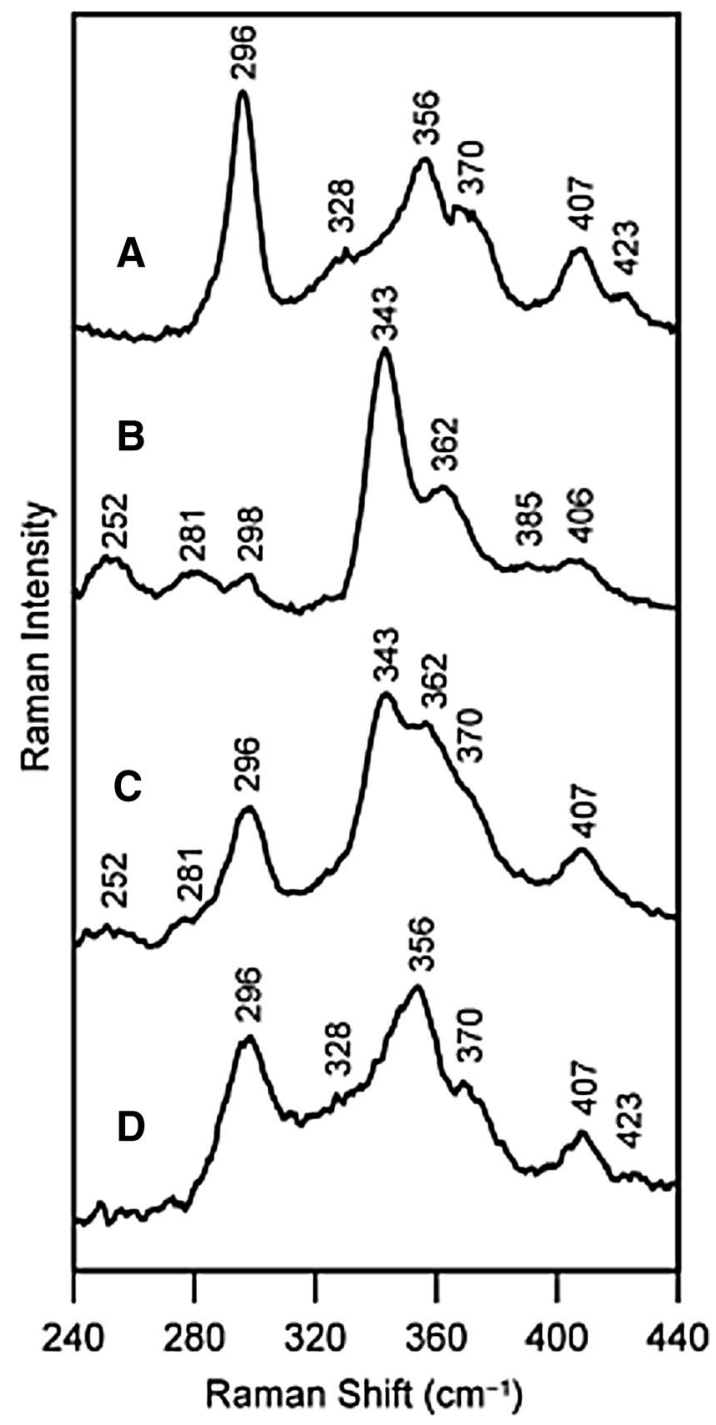

Fig. 7 Oxygen-induced [4Fe-4S]-to-[2Fe-2S] cluster conversion on IscU monitored by RR spectroscopy. RR spectra of $\mathbf{a} 2 \times[2 \mathrm{Fe}-2 \mathrm{~S}]^{2+}$ $\mathrm{IscU}, \mathbf{b}[4 \mathrm{Fe}-4 \mathrm{~S}]^{2+} \mathrm{IscU}, \mathbf{c}[4 \mathrm{Fe}-4 \mathrm{~S}]^{2+}$ IscU after exposure to $\mathrm{O}_{2}$ for $1 \mathrm{~min}$, and $\mathbf{d}[4 \mathrm{Fe}-4 \mathrm{~S}]^{2+}$ IscU after exposure to air for $1 \mathrm{~min}$. Spectra were recorded using $458 \mathrm{~nm}$ excitation and $100 \mathrm{~mW}$ laser power at $16 \mathrm{~K}$. Reprinted with permission from Chandramouli et al. [26]. Copyright (2007) American Chemical Society 
oxygen coincide with those of the cluster initially formed in IscU, indicating that the clusters are structurally analogous. This capacity of IscU to accommodate either $2 \mathrm{Fe}-2 \mathrm{~S}$ or $4 \mathrm{Fe}-4 \mathrm{~S}$ cluster was linked to its role in facilitated maturation of distinct $\mathrm{Fe}-\mathrm{S}$ proteins in response to redox status of the cell and/or oxygen level. Third, since RR spectra are sensitive to the ligand type and conformation, they have provided valuable information about coordination of the newly formed clusters. For instance, the anomalously high frequencies observed in RR spectra of $[2 \mathrm{Fe}-2 \mathrm{~S}]^{2+}$ cluster formed in Isc $U$ ( $A_{\mathrm{g}}^{\mathrm{t}}$ and $\mathrm{B}_{3 \mathrm{u}}^{\mathrm{t}}$ modes at 356 and $296 \mathrm{~cm}^{-1}$, respectively) were indicative of non-cysteine ligation. They furthermore coincided with those reported for $2 \mathrm{Fe}-2 \mathrm{~S}$ clusters with one serinate ligand $\left(A_{\mathrm{g}}^{\mathrm{t}}\right.$ within $332-356 \mathrm{~cm}^{-1}$ and $\mathrm{B}_{3 \mathrm{u}}^{\mathrm{t}}$ within $289-302 \mathrm{~cm}^{-1}$ range). The totally symmetric breathing mode of the subsequently formed [ $4 \mathrm{Fe}-4 \mathrm{~S}]^{2+}$ center $\left(434 \mathrm{~cm}^{-1}\right)$ is also higher than in all-cysteinyl clusters, Table 1, suggesting a non-cysteinyl ligation at one site or unusual $\mathrm{H}$ bonding and/or Fe-S-C-C dihedral angles of the cluster [26]. Fourth, RR spectroscopy has helped to establish the possible roles of A-type proteins in the cluster formation. It was first suggested that IscA can play a role of an alternative scaffold for assembly of $[2 \mathrm{Fe}-2 \mathrm{~S}]^{2+}$ cluster when Isc U was absent from the reaction mixture [78, 79], and subsequently demonstrated that its primary functions include $\mathrm{Fe}-\mathrm{S}$ shuttling [80] and Fe-donation [28, 81]. Also, in NIF-specific Fe-S cluster biogenesis, IscA (i.e., Nif IscA) was capable of binding one iron atom per homodimer, in a cluster with mixed Cys/ Asp coordination, as indicated by RR bands at 298, 338 and $397 \mathrm{~cm}^{-1}[27,28]$. The $\mathrm{Fe}^{3+}$-bound IscA, was shown to be a competent iron source for in vitro NifS-mediated $2 \mathrm{Fe}-2 \mathrm{~S}$ cluster assembly on the N-terminal domain of NifU. Furthermore the ${ }^{\mathrm{Nif}} \mathrm{IscA}$ could be rapidly and reversibly converted from one $[2 \mathrm{Fe}-2 \mathrm{~S}]^{2+}$ to one $[4 \mathrm{Fe}-4 \mathrm{~S}]^{2+}$ containing form (per homodimer). The former is formed through $\mathrm{O}_{2}$-induced cleavage of the $[4 \mathrm{Fe}-4 \mathrm{~S}]^{2+}$ cluster, and the latter via twoelectron reductive coupling of two $[2 \mathrm{Fe}-2 \mathrm{~S}]^{2+}$ clusters. Taken together, it was proposed that A-type proteins can play a role of specific iron donors for cluster assembly on U-type scaffolds and for repair of $[3 \mathrm{Fe}-4 \mathrm{~S}]^{+}$clusters, and furthermore that they can function as carriers of $2 \mathrm{Fe}-2 \mathrm{~S}$, rather than $4 \mathrm{Fe}-4 \mathrm{~S}$ clusters, assembled on U-type proteins to acceptor proteins $[27,28]$.

\section{Substrate activation and catalysis}

RR has been a crucial experimental tool in the investigations of $\mathrm{Fe}-\mathrm{S}$ proteins in which the cluster, with typically non-all-cysteinyl coordination, represents a site for substrate binding, such as in radical-S-adenosylL-methionine (SAM) enzymes [34] and aconitases [35]. The latter enzymes catalyze the isomerization of citrate to iso-citrate in an active site that houses a $[4 \mathrm{Fe}-4 \mathrm{~S}]^{2+}$ cluster and directly binds the substrate; both inactive (i.e., $[3 \mathrm{Fe}-4 \mathrm{~S}]^{1+}$ containing) and the activated forms of the cluster have been characterized by RR and their $\mathrm{Fe}-\mathrm{S}$ modes assigned [34]. Members of the large family of radical-SAM enzymes catalyze diverse radical reactions in a variety of biosynthetic processes via reductive cleavage of SAM. They typically possess three cysteine residues coordinating three iron atoms of a $4 \mathrm{Fe}-4 \mathrm{~S}$ cluster at the active site of the enzyme. The remaining ligand of the fourth, socalled unique $\mathrm{Fe}$, at which substrate binding and activation occur, is in the absence of SAM not known. RR spectroscopy significantly contributed to the current understanding of the physiological state of the $[4 \mathrm{Fe}-4 \mathrm{~S}]^{2+/ 1+}$ cluster in the active site and of the nature of the second $\mathrm{Fe}-\mathrm{S}$ cluster of unknown function, which is present in some of these proteins [32-34]. Namely, due to the incomplete coordination, the $[4 \mathrm{Fe}-4 \mathrm{~S}]^{2+}$ clusters in proteins from the radical-SAM family are particularly prone to degradation, which led to conflicting data in the literature about the physiologically relevant type/state of the cluster. RR spectroscopy provided crucial evidence about $[4 \mathrm{Fe}-4 \mathrm{~S}]$ cluster sensitivity, demonstrating its prompt conversion to a quasistable $[2 \mathrm{Fe}-2 \mathrm{~S}]^{2+}$ form under aerobic conditions, which sometimes proceeds via formation of a $[3 \mathrm{Fe}-4 \mathrm{~S}]^{1+}$ cluster, explaining the presence of $[2 \mathrm{Fe}-2 \mathrm{~S}]^{2+}$ or $[3 \mathrm{Fe}-4 \mathrm{~S}]^{1+}$ forms in aerobically purified proteins [32].

$\mathrm{RR}$ has been employed, in combination with EPR and Mössbauer spectroscopies, in investigations of the two $\mathrm{Fe}-\mathrm{S}$ clusters in BioB, the enzyme responsible for converting dethiobiotin to biotin by inserting a sulfur atom between the two carbons of the substrate [32]. It was shown that $\mathrm{BioB}$ carries one $[2 \mathrm{Fe}-2 \mathrm{~S}]^{2+}$ cluster with partial noncysteinyl ligation (the most prominent bands at 301, 331 and $349 \mathrm{~cm}^{-1}$ ) and one $[4 \mathrm{Fe}-4 \mathrm{~S}]^{2+/ 1+}$ cluster, which binds $\mathrm{SAM}$ at a unique $\mathrm{Fe}$ site (characteristic bands at 338 and $364 \mathrm{~cm}^{-1}$ ). The latter undergoes $\mathrm{O}_{2}$-induced degradation via formation of a distinct $[2 \mathrm{Fe}-2 \mathrm{~S}]^{2+}$ intermediate, with broadened bands at 292, 336 and $398 \mathrm{~cm}^{-1}$. RR evidence supported direct interaction of SAM with the unique iron of the $[4 \mathrm{Fe}-4 \mathrm{~S}]^{2+}$ cluster and indicated that the $[2 \mathrm{Fe}-2 \mathrm{~S}]^{2+}$ center can act as an immediate $\mathrm{S}$-donor during the turnover cluster transformations [32]. Similarly, RR helped characterize the properties of the $\mathrm{Fe}-\mathrm{S}$ clusters in MOCS 1 that catalyzes the conversion of a guanosine derivative to precursor $\mathrm{Z}$ during molybdenum cofactor biosynthesis. It also helped to validate the controversial work with in vitro reconstituted recombinant enzymes [34], as the anaerobically purified MOCS1 differed from the enzyme obtained by in vitro reconstitution of the clusters under anaerobic conditions and from that purified under aerobic conditions. The current view is that the two $[4 \mathrm{Fe}-4 \mathrm{~S}]^{2+}$ cluster containing MOCS1 is the catalytically competent form, although it could not be experimentally detected in the intact form due 
to a rapid degradation in the presence of oxygen to semistable $[2 \mathrm{Fe}-2 \mathrm{~S}]^{2+}$ and $[3 \mathrm{Fe}-4 \mathrm{~S}]^{0}$ intermediates [34].

\section{Regulation of gene expression}

$\mathrm{Fe}-\mathrm{S}$ clusters are present in transcriptional and translational regulators of gene expression, in which upon environmental stimuli, they undergo transformation (e.g., cluster assembly, conversion or redox reaction) that triggers respective cellular response mechanisms. In combination with other spectroscopic techniques, RR has revealed the details about the cluster formation, type and coordination along these processes. The studied systems include proteins that are stressresponsive transcriptional regulators, and/or participate in iron metabolism, such as BolA proteins and homologues [8, 39]. Among the latter is Fra2, which plays a key role in regulating the iron homeostasis in yeasts. RR spectroscopy revealed molecular details about the complex formation between Fra2 and cytosolic monothiol glutaredoxins (Grx3/4) via bridging though a $[2 \mathrm{Fe}-2 \mathrm{~S}]^{2+}$ cluster. The spectra of the Grx3-Fra2 complex indicated a presence of mixed cysteinyl- and histidyl-ligated $[2 \mathrm{Fe}-2 \mathrm{~S}]^{2+}$ cluster, based on the appearance of two low-frequency modes at 275 and $300 \mathrm{~cm}^{-1}$, characteristic of partial histidyl ligation $[36,38]$. This type of coordination is nevertheless not exclusive in the complexes formed between BolA (and homologues) with Grx, as all-cysteinyl and Rieske-type [2Fe-2S] clusters could also be identified from RR spectra [8]. RR has, furthermore also revealed a notable similarity between [2Fe-2S]-bridged complexes in yeast and human systems involving human BolA2 and Glrx5 [37].

RR spectroscopy has provided a remarkable evidence for inter-conversion between $[4 \mathrm{Fe}-4 \mathrm{~S}]^{2+}$ and $[2 \mathrm{Fe}-2 \mathrm{~S}]^{2+}$ clusters in fumarate and nitrate reduction (FNR) regulatory proteins, which are bacterial $\mathrm{O}_{2}$-sensing transcription factors that control the switch between aerobic and anaerobic metabolism [10]. As a response to increased oxygen levels, the $[4 \mathrm{Fe}-4 \mathrm{~S}]^{2+}$ cluster in these proteins undergoes a rapid conversion to a $[2 \mathrm{Fe}-2 \mathrm{~S}]^{2+}$ cluster, triggering a dimer-to-monomer transition and loss of site-specific DNA binding. RR spectra of anaerobically reconstituted FNR reveal all cysteine-ligated $[4 \mathrm{Fe}-4 \mathrm{~S}]^{2+}$ cluster (bands at 335 , 354,366 and $392 \mathrm{~cm}^{-1}$ ) that can be assigned under effective $D_{2 d}$ symmetry, similar to those of $4 \mathrm{Fe}-4 \mathrm{~S} \mathrm{Fd}$ (Fig. 8). After exposure to air, the cluster is converted into an atypical $[2 \mathrm{Fe}-2 \mathrm{~S}]^{2+}$ center, which displays low-intensity RR bands at 293,345 , and $395 \mathrm{~cm}^{-1}$ that were attributed to cysteine persulfide-ligated $[2 \mathrm{Fe}-2 \mathrm{~S}]^{2+}$. This conversion of $[4 \mathrm{Fe}-4 \mathrm{~S}]^{2+}$ to cysteine persulfide-ligated $[2 \mathrm{Fe}-2 \mathrm{~S}]^{2+}$ cluster in FNR is reversible under anaerobic conditions in the presence of DTT and excess of ferrous iron (Fig. 8). The formation of cysteine persulfide-ligated $[2 \mathrm{Fe}-2 \mathrm{~S}]^{2+}$ was correlated to $\mathrm{O}_{2}$-induced $\mathrm{S}^{2-}$ to $\mathrm{S}^{0}$ oxidation and the molecular

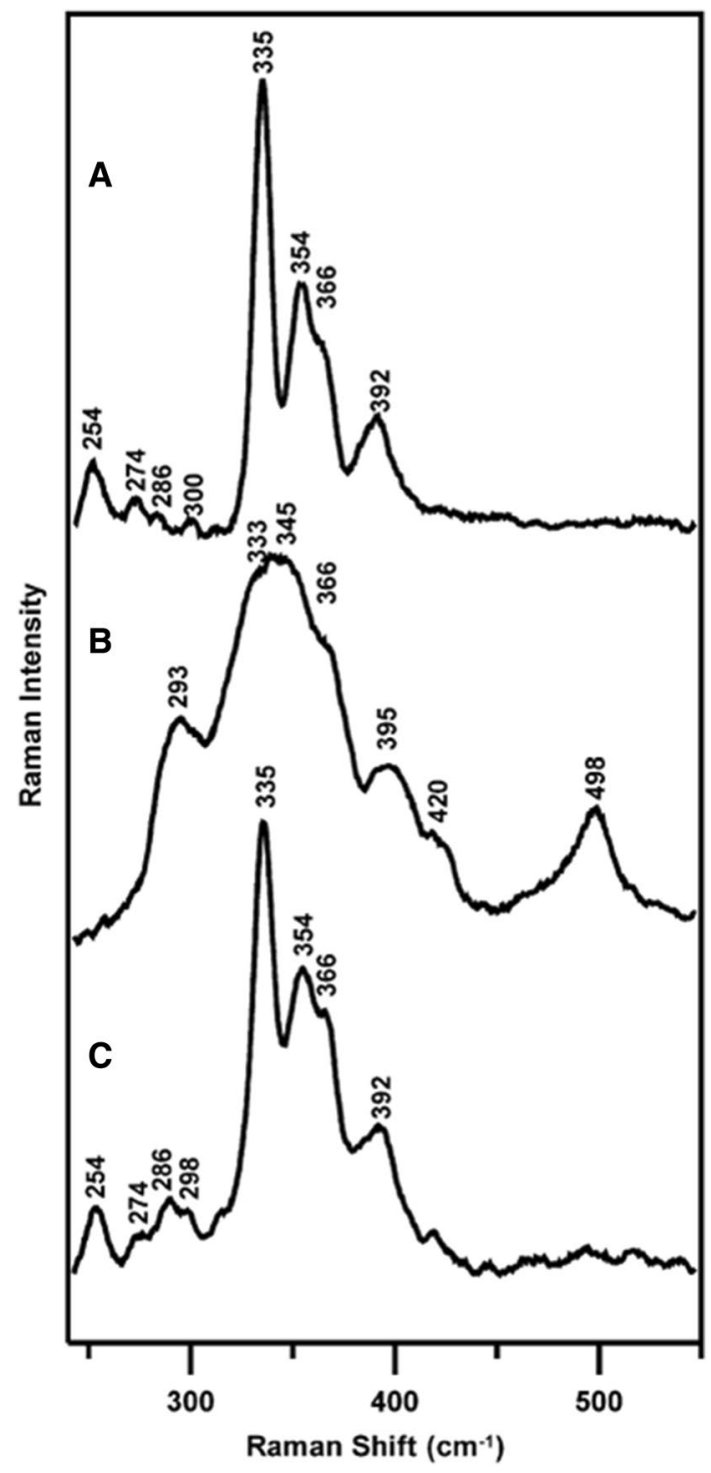

Fig. 8 RR studies of the $[4 \mathrm{Fe}-4 \mathrm{~S}]^{2+}$ and $[2 \mathrm{Fe}-2 \mathrm{~S}]^{2+}$ inter-conversion in FNR. a Reconstituted $[4 \mathrm{Fe}-4 \mathrm{~S}]^{2+}-\mathrm{FNR}$ in the presence of GSH. b $[2 \mathrm{Fe}-2 \mathrm{~S}]^{2+}-\mathrm{FNR}$ obtained by exposing the sample (a) to air for 20 min and $\mathbf{c}$ after incubation of the sample (b) with DTT and ferrous ammonium sulfate under anaerobic conditions for $20 \mathrm{~min}$. The spectra are recorded at $21 \mathrm{~K}$ with $458 \mathrm{~nm}$ laser excitation of $140 \mathrm{~mW}$ power. Reprinted with permission from PNAS from Zhang et al. [10]

mechanism of $\mathrm{O}_{2}$ sensing by FNR, suggesting unique pathways for the assembly and/or repair of biological [4Fe-4S] clusters [10].

Together with optical and Mössbauer spectroscopies, $\mathrm{RR}$ has been used to address the controversial views on the type of the physiological cluster in the NO-sensing module of transcription factor NsrR from the Rrf2 family, which controls expression of genes in response to $\mathrm{NO}$ in a wide range of bacteria. It was demonstrated that initially observed $2 \mathrm{Fe}-2 \mathrm{~S}$ cluster in NsrR was actually an artifact, and that the protein houses a $[4 \mathrm{Fe}-4 \mathrm{~S}]^{2+}$ cluster, with $(\mathrm{Fe}-\mathrm{S})^{\mathrm{t}}$ at 
$\sim 363$ and $389 \mathrm{~cm}^{-1}$ and $(\mathrm{Fe}-\mathrm{S})^{\mathrm{b}}$ stretching modes at 343 and $389 \mathrm{~cm}^{-1}$, which were assigned by analogy with simple Fd under idealized $T_{d}$ or $D_{2 d}$ symmetry [5]. The high frequency of the symmetric $(\mathrm{Fe}-\mathrm{S})^{\mathrm{b}}$, found at $343 \mathrm{~cm}^{-1}$, was rationalized in terms of oxygenic ligation in the cluster, with a highly conserved Glu being envisaged as a possible candidate for this ligand [5].

\section{Fe-S clusters in complex multiple-cofactor centers}

Due to potential biotechnological applications of hydrogenases for hydrogen production as a clean fuel, intensive research efforts have been made in order to understand the catalytic mechanism of these enzymes, which catalyze reversible cleavage of hydrogen. RR has recently revealed structural insights into catalytic intermediate species in several of these enzymes [7, 82, 83]. Depending on the type and the source, hydrogenases can carry a variable number of different $\mathrm{Fe}-\mathrm{S}$ clusters that are either essential for the ET and/or together with the binuclear center, constitute the active site. NiFe hydrogenases typically possess three $\mathrm{Fe}-\mathrm{S}$ centers which conduct electrons from the active site to the physiological redox partner. In combination with theoretical approaches and FTIR spectroscopy, RR provided molecular details on the heterobimetallic active site and the $\mathrm{Fe}-\mathrm{S}$ clusters in regulatory NiFe hydrogenase $(\mathrm{RH})$ in oxidized and $\mathrm{H}_{2}$-reduced states. It has been used to probe the $[4 \mathrm{Fe}-4 \mathrm{~S}]^{2+}$ clusters, which revealed bands below $400 \mathrm{~cm}^{-1}$ that diminish upon $\mathrm{H}_{2}$-incubation, indicating reduction to the RR-silent $[4 \mathrm{Fe}-4 \mathrm{~S}]^{1+}$ state, and to simultaneously monitor the active site (i.e., $\mathrm{Fe}-\mathrm{CN}$ and $\mathrm{Fe}-\mathrm{CO}$ stretching modes) that show bands at higher $\left(400-600 \mathrm{~cm}^{-1}\right)$ frequencies [82]. Similarly, RR spectra of membrane-bound hydrogenase, from which the contributions of the $\mathrm{Fe}-\mathrm{S}$ clusters were excluded by $\mathrm{H}_{2}$-reduction, revealed modes originating from the heterobimetallic active site that are sensitive to its structure [83]. Furthermore, in combination with FTIR spectroscopy, RR has provided new insights into the nature of catalytic intermediates of a FeFe hydrogenase, which houses a Fd-like $[4 \mathrm{Fe}-4 \mathrm{~S}]^{2+}$ cluster that is covalently bound via a cysteinyl thiolate link to one of the $\mathrm{Fe}$ atoms in the catalytic site. In these enzymes the cluster acts as an electron entry site [7]. RR allowed for simultaneous observation of the $[4 \mathrm{Fe}-4 \mathrm{~S}]^{2+}$ cluster, displaying 336, 348 and $358 \mathrm{~cm}^{-1}$ bands (Fig. 9) and $\mathrm{Fe}-\mathrm{CN}$ and $\mathrm{Fe}-\mathrm{CO}$ stretching modes of the active center at higher frequencies, in 'as-isolated', $\mathrm{H}_{2}$-reduced, thionineoxidized and CO-bound states of the enzyme. Furthermore, RR was capable of identifying a transient catalytic intermediate, in which the active site is in the mixed valence $\mathrm{Fe}^{+} \mathrm{Fe}^{2+}$ state and the cluster is reduced, $[4 \mathrm{Fe}-4 \mathrm{~S}]^{1+}$. It was assigned to a deprotonated $\mathrm{H}$ cluster intermediate, which is formed first during the biological hydrogen production and had never been experimentally observed before, allowing

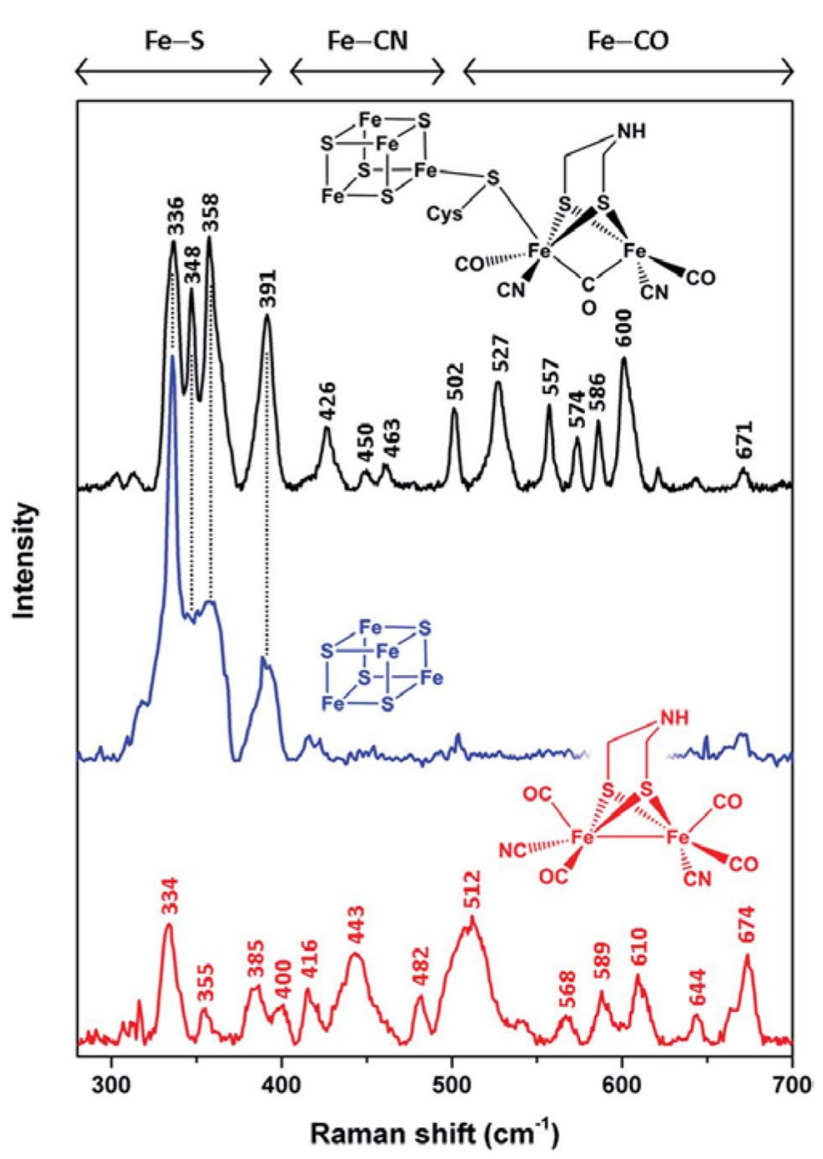

Fig. 9 Low-temperature RR spectra of [FeFe] hydrogenase HydA1 and model compounds. The reduced synthetic Fe-Fe-aza-dithiolate complex (red, $514 \mathrm{~nm}$ excitation), thionine-oxidized apo-HydA1 (blue, $458 \mathrm{~nm}$ ), and in vitro-matured holo-HydA1 aza-dithiolate complex (black, $488 \mathrm{~nm}$ excitation). Spectral regions reflecting normal modes with major contributions from $\mathrm{Fe}-\mathrm{S}, \mathrm{Fe}-\mathrm{CN}$, and $\mathrm{Fe}-\mathrm{CO}$ coordinates are indicated. Reprinted from Katz et al. [7]— published by The Royal Society of Chemistry

for establishment of a more complete picture of the catalytic cycle of FeFe hydrogenases [7].

Other proteins that house complex cofactors include sulfite reductases and nitrogenases, among others. The former carry a siroheme, in which the $4 \mathrm{Fe}-4 \mathrm{~S}$ cluster is covalently bridged to the heme iron by a cysteinyl $\mathrm{S}$ atom [40]. Low frequency of RR spectra obtained with excitation in the siroheme Soret or Q bands are dominated by heme modes, while the $4 \mathrm{Fe}-4 \mathrm{~S}$ cluster can be selectively enhanced with 488 or $458 \mathrm{~nm}$ excitation. RR spectra are comparable with those of other $4 \mathrm{Fe}-4 \mathrm{~S}$ proteins; however, the $\mathrm{A}_{1}^{\mathrm{b}}$ breathing mode was found at $342 \mathrm{~cm}^{-1}$, which is significantly higher than that observed in the other analogous clusters (Table 1). Additional ${ }^{34} \mathrm{~S}$-sensitive features observed at 352 and $393 \mathrm{~cm}^{-1}$ in the spectra of sulfite erductase obtained with Soret-band excitation were putatively attributed to a bridging thiolate ligand [40]. The information that can be extracted 
from RR spectra on the unique cluster in nitrogenases is still relatively limited, due to inherently weak signals. In fact the first RR spectrum of a nitrogenase from Azotobacter vinelandii that houses the 'FeMo-cofactor' in the active site (i.e., [Mo-7Fe-9S-Ci], where $\mathrm{Ci}$ is carbide), has been reported only recently, employing high laser power and exceptionally long accumulation times. The spectra obtained with $488 \mathrm{~nm}$ excitation reveal $\mathrm{A}_{1}^{\mathrm{b}}$ mode at $338 \mathrm{~cm}^{-1}$, together with two additional bands 356 and $382 \mathrm{~cm}^{-1}$ in nitrogenase [41].

\section{Outlook}

The continuous progress in experimental methodologies that include more efficient protein expression systems and purification methods, alongside with more sensitive and faster spectroscopic techniques, allow us nowadays to identify and characterize $\mathrm{Fe}-\mathrm{S}$ clusters in exceptionally complex, unstable and transient systems and processes. Due to these advances, we have been able to encounter previously undetected $\mathrm{Fe}-\mathrm{S}$ clusters in known proteins, to propose new roles for the clusters and to improve our understanding of physiologically relevant and unusually complex cofactors that integrate $\mathrm{Fe}-\mathrm{S}$ clusters. Being sensitive to the type, ligands and configuration of a cluster, RR spectroscopy has been playing an important part in these discoveries. Some of the recent achievements include the evidence for the presence of a $[2 \mathrm{Fe}-2 \mathrm{~S}]^{2+}$ cluster in a kinase/phosphatase Asp1 that regulates cell morphogenesis in yeasts [9], characterization of the $[4 \mathrm{Fe}-4 \mathrm{~S}]^{2+}$ cluster in $\mathrm{HydF}$, a protein involved in the maturation of organometallic $\mathrm{H}$ cluster of $\mathrm{Fe}-\mathrm{Fe}$ hydrogenase [4] and elucidation of the missing pieces (i.e., the transient catalytic intermediates) of the catalytic cycle puzzle in hydrogenases [7, 82], which provide the key information about biological hydrogen activation. We believe that RR spectroscopy has a bright future in illuminating the structure and function of $\mathrm{Fe}-\mathrm{S}$ clusters that are still to come to our lab benches.

Acknowledgements This article is based upon work from COST Action CA15133, supported by COST (European Cooperation in Science and Technology). The financial support from Project LISBOA-010145-FEDER-007660 (Microbiologia Molecular, Estrutural e Celular) funded by FEDER funds through COMPETE2020 - Programa Operacional Competitividade e Internacionalização (POCI) and national funds through FCT - Fundação para a Ciência e a Tecnologia is gratefully acknowledged.

Open Access This article is distributed under the terms of the Creative Commons Attribution 4.0 International License (http://creativeco mmons.org/licenses/by/4.0/), which permits use, duplication, adaptation, distribution and reproduction in any medium or format, as long as you give appropriate credit to the original author(s) and the source, provide a link to the Creative Commons license and indicate if changes were made.

\section{References}

1. Spiro TG, Czernuszewicz RS (1995) Methods Enzymol 246:416-460

2. Siebert F, Hildebrandt P (2008) Vibrational spectroscopy in life sciences. Wiley-VCH Verlag GmbH \& Co, Weinheim

3. Bandyopadhyay S, Chandramouli K, Johnson MK (2008) Biochem Soc Trans 36:1112-1119

4. Berggren G, Garcia-Serres R, Brazzolotto X, Clemancey M, Gambarelli S, Atta M, Latour JM, Hernández HL, Subramanian S, Johnson MK, Fontecave M (2014) J Biol Inorg Chem 19:75-84

5. Crack JC, Munnoch J, Dodd EL, Knowles F, Bassam MMA, Kamali S, Holland AA, Cramer SP, Hamilton CJ, Johnson MK, Thomson AJ, Hutchings MI, Le Brun NE (2015) J Biol Chem 290:12689-12704

6. Gao H, Subramanian S, Coutourier J, Naik SG, Kim SK, Leustek T, Knaff DB, Wu HC, Vignols F, Huyn BH, Rouhier N, Johnson MK (2013) Biochemistry 52:6633-6645

7. Katz S, Noth J, Horch M, Shafaat HS, Happe T, Hildebrandt P, Zebger I (2016) Chem Sci 7:6746-6752

8. Roret T, Tsan P, Couturier J, Zhang B, Johnson MK, Rouhier N, Didierjean C (2014) J Biol Chem 289:24588-24598

9. Wang H, Nair VS, Holland AA, Capolicchio S, Jessen HJ, Johnson MK, Shears SB (2015) Biochemistry 54:6462-6474

10. Zhang B, Crack JC, Subramanian S, Green J, Thomson AJ, Le Brun NE, Johnson MK (2012) Proc Natl Acad Sci USA 109:15734-15739

11. Moe E, Sezer M, Hildebrandt P, Todorovic S (2015) ChemComm 51:3255-3257

12. Moe E, Rollo F, Silveira CM, Sezer M, Hildebrandt P, Todorovic S (2018) Spectrochim Acta A 188:149-154

13. Brereton PS, Duderstadt RE, Staples CR, Johnson MK, Adams MWW (1999) Biochemistry 38:10594-10605

14. Czernuszewicz RS, LeGall J, Moura I, Spiro TG (1986) Inorg Chem 25:696-700

15. Czernuszewicz RS, Macor KA, Johnson MK, Gewirth A, Spiro TG (1987) J Am Chem Soc 109:7178-7187

16. Czernuszewicz RS, Kilpatrick LK, Koc SA, Spiro TG (1994) J Am Chem Soc 116:7134-7141

17. Dave BC, Czernuszewicz RS, Prickril BC, Kurtz DMJ (1994) Biochemistry 33:3572-3576

18. Han S, Czernuszewicz RS, Spiro TG (1989) J Am Chem Soc 111:3496-3504

19. Han S, Czernuszewicz RS, Kimura T, Adams MWW, Spiro TG (1989) J Am Chem Soc 111:3505-3511

20. Johnson MK, Czernuszewicz RS, Spiro TG, Fee JA, Sweeney WV (1983) J Am Chem Soc 105:6671-6678

21. Pinto AF, Todorovic S, Hildebrandt P, Yamazaki M, Amano F, Igimi S, Romao CV, Teixeira M (2011) J Biol Inorg Chem 16:501-510

22. Agar JN, Krebs C, Frazzon J, Huynh BH, Dean DR, Johnson MK (2000) Biochemistry 39:7856-7862

23. Agar JN, Yuvaniyama P, Jack RF, Cash VL, Smith AD, Dean DR, Johnson MK (2000) J Biol Inorg Chem 5:167-177

24. Agar JN, Zheng LM, Cash VL, Dean DR, Johnson MK (2000) J Am Chem Soc 122:2136-2137

25. Bandyopadhyay S, Naik SG, O'Carroll IP, Huynh BH, Dean DR, Johnson MK, Dos Santos PC (2008) J Biol Chem 283:14092-14099

26. Chandramouli K, Unciuleac MC, Naik S, Dean DR, Huynh BH, Johnson MK (2007) Biochemistry 46:6804-6811

27. Mapolelo DT, Zhang B, Naik SG, Huynh BH, Johnson MK (2012) Biochemistry 51:8056-8070

28. Mapolelo DT, Zhang B, Naik SG, Huynh BH, Johnson MK (2012) Biochemistry 51:8071-8084 
29. Nobre LS, Garcia-Serres R, Todorovic S, Hildebrandt P, Teixeira M, Latour JM, Saraiva LM (2014) PLoS One 9:e95222

30. Yuvaniyama P, Agar JN, Cash VL, Johnson MK, Dean DR (2000) Proc Natl Acad Sci USA 97:599-604

31. Crouse BR, Sellers VM, Finnegan MG, Dailey HA, Johnson MK (1996) Biochemistry 35:16222-16229

32. Cosper MM, Jameson GNL, Hernandez HL, Krebs C, Huynh BH, Johnson MK (2004) Biochemistry 43:2007-2021

33. Duin EC, Lafferty ME, Crouse BR, Allen RM, Sanyal I, Flint DH, Johnson MK (1997) Biochemistry 36:11811-11820

34. Hanzelmann P, Hernandez HL, Menzel C, Garcia-Serres R, Huynh BH, Johnson MK, Mendel RR, Schindelin H (2004) J Biol Chem 279:34721-34732

35. Kilpatrick LK, Kennedy MC, Beinert H, Czernuszewicz RS, Qiu D, Spiro TG (1994) J Am Chem Soc 16:4053-4061

36. Li H, Mapolelo DT, Dingra NN, Keller G, Riggs-Gelasco PJ, Winge DR, Johnson MK, Outten CE (2011) J Biol Chem 286:867-876

37. Li H, Mapolelo DT, Randeniya S, Johnson MK, Outten CE (2012) Biochemistry 51:1687-1696

38. Li HR, Mapolelo DT, Dingra NN, Naik SG, Lees NS, Hoffman BM, Riggs-Gelasco PJ, Huynh BH, Johnson MK, Outten CE (2009) Biochemistry 48:9569-9581

39. Zhang B, Bandyopadhyay S, Shakamuri P, Naik SG, Huynh BH, Couturier J, Rouhier N, Johnson MK (2013) J Am Chem Soc 135:15153-15164

40. Madden JF, Han S, Siegal LM, Spiro TG (1989) Biochemistry 28:5471-5477

41. Maiuri M, Delfino I, Cerullo C, Manzoni C, Pelmenschikov V, Guo Y, Wang H, Gee LB, Dapper CH, Newton WE, Cramer SP (2015) J Inorg Biochem 153:128-135

42. Fu WG, Drozdzewski PM, Davies MD, Sligar SG, Johnson MK (1992) J Biol Chem 267:15502-15510

43. Todorovic S, Leal SS, Salgueiro CA, Zebger I, Hildebrandt P, Murgida DH, Gomes CM (2007) Biochemistry 46:10733-10738

44. Johnson MK, Duderstadt RE, Duin EC (1999) Adv Inorg Chem 47:1-82

45. Leggate EJ, Bill E, Essigke T, Ullmann GM, Hirst J (2004) Proc Natl Acad Sci USA 101:10913-10918

46. Verhagen MFJM, Link TA, Hagen WR (1995) FEBS Lett 361:75-78

47. Duff JLC, Breton JL, Butt JN, Armstrong FA, Thomson AJ (1996) J Am Chem Soc 118:8593-8603

48. Fawcett SE, Davis D, Breton JL, Thomson AJ (1998) Biochem J 335:357-368

49. George SJ, Armstrong FA, Hatchikian EC, Thomson AJ (1989) Biochem J 264:275-284

50. Heering HA, Bulsink YBM, Hagen WR, Meyer T (1995) Eur J Biochem 232:811-817

51. Angove HC, Yoo SJ, Burgess BK, Munck E (1997) J Am Chem Soc 119:8730-8731

52. Angove HC, Yoo SJ, Munck E, Burgess BK (1998) J Biol Chem 273:26330-26337

53. Grazina R, Pauleta S, Moura JJG, Moura I (2013) In: Reedijk J, Poeppelmeier K (eds) Comprehensive inorganic chemistry II. Elsevier, Oxford, pp 103-148

54. Liu J, Chakraborty S, Hosseinzadeh P, Yu Y, Tian S, Petrik I, Bhagi A, Lu Y (2014) Chem Rev 114:4366-4469

55. Vincente JB, Teixeira M (2005) J Biol Chem 280:34599-34608

56. LeGall J, Prickril BC, Moura I, Xavier AV, Moura JJG, Huynh BH (1988) Biochemistry 27:1636-1642
57. Meyer J, Moulis JM (2006) Handbook of Metalloproteins. John Wiley \& Sons, New Jersey

58. Xiao Z, Lavery MJ, Ayhan M, Scrofani SDB, Wilce MCJ, Guss JM, Tregloan PA, George GN, Wedd AG (1998) J Am Chem Soc 120:4135-4150

59. Todorovic S, Murgida DH (2016) Surface enhanced raman scattering of biological molecules. In: Meyers RA (ed) Encyclopedia of analytical chemistry. Wiley, New Jersey, pp 1-29

60. Aliverti A, Hagen WR, Zanetti G (1995) FEBS Lett 368:220-224

61. Dutton PL (1971) Biochim Biophys Acta 226:63-80

62. Fourmond V, Léger (2017) Protein electrochemistry: questions and answers. In: Jeuken LJC (ed) Biophotoelectrochemistry: from bioelectrochemistry to biophotovoltaics. Springer, Cham, pp 1-41

63. Zu Y, Di Bernardo S, Yagi T, Hirst J (2002) Biochemistry 41:10056-10069

64. Leger C, Bertrand P (2008) Chem Rev 108:2379-2438

65. Johnson DC, Dean DR, Smith AD, Johnson MK (2005) Annu Rev Biochem 74:274-281

66. Meyer J (2008) J Biol Inorg Chem 13:157-170

67. Xiao Y, Wang H, George SJ, Smith MC, Adams MWW, Jenney JFE, Sturhahn W, Alp EE, Zhao J, Yoda Y, Dey A, Solomon EI, Cramer SP (2005) J Am Chem Soc 127:14596-14606

68. Rotsaert FAJ, Pikus JD, Fox BG, Markley JL, Sanders-Loehr J (2003) J Biol Inorg Chem 8:318-326

69. Xiao Y, Tan ML, Ichiye T, Wang H, Guo Y, Smith MC, Meyer J, Sturhahn W, Alp Zhao J, Yoda Y, Cramer SP (2008) Biochemistry 47:6612-6627

70. Iwasaki T, Watanabe E, Ohmori D, Imai T, Urushiyama A, Akiyama M, Hayashi-Iwasaki Y, Cosper NJ, Scott RA (2000) J Biol Chem 275:25391-25401

71. Iwasaki T, Kounosu A, Kolling DR, Crofts AR, Dikanov SA, Jin A, Imai T, Urushiyama A (2004) J Am Chem Soc 126:4788-4789

72. Backes G, Mino Y, Loehr T, Meyer T, Cusanovich MA, Sweeney WV, Adman ET, Sanders-Loehr J (1991) J Am Chem Soc 113:2055-2064

73. Fuss JO, Tsai CL, Ishida JP, Tainer JA (2015) Biochim Biophys Acta 1853:1253-1271

74. White MF, Dillingham MS (2012) Curr Opin Struct Biol 22:94-100

75. Lukianova OA, David SS (2005) Curr Opin Chem Biol 9:145-151

76. Fu W, O’Handley S, Cunningham RP, Johnson MK (1992) J Biol Chem 267:16135-16137

77. Boal AK, Yavin E, Lukianova OA, O'Shea VL, David SS, Barton JK (2005) Biochemistry 44:8397-8407

78. Krebs C, Agar JN, Smith AD, Frazzon J, Dean DR, Huynh BH, Johnson MK (2001) Biochemistry 40:14069-14080

79. Ollagnier de Choudens C, Mattioli T, Takahashi Y, Fontecave M (2001) J Biol Chem 276:22604-22607

80. Ollagnier-de-Choudens S, Sanakis Y, Fontecave M (2004) J Biol Inorg Chem 9:828-838

81. Wang W, Huang H, Tan G, Si F, Liu M, Landry AP, Lu J, Ding H (2010) Biochem J 432:429-436

82. Horch M, Schoknecht J, Mroginski MA, Lenz O, Hildebrandt P, Zebger I (2014) J Am Chem Soc 136:9870-9873

83. Siebert E, Horch M, Rippers Y, Fritsch J, Frielingsdorf S, Lenz O, Velasquez Escobar F, Siebert F, Paasche L, Kuhlman U, Lendzian F, Mroginski MA, Zebger I, Hildebrandt P (2013) Angew Chem Int Ed 52:5162-5165 